\section{Exploring the Potential of Lettuce (Lactuca sativa L.) as an Early Crop in Florida's Sandy Soils}

\author{
Gustavo F. Kreutz and Germán V. Sandoya \\ Horticultural Sciences Department, Everglades Research and Education \\ Center, University of Florida, 3200 East Palm Beach Road, Belle Glade, FL \\ 33430
}

Gary K. England

Hastings Agricultural Extension Center, University of Florida (Emeritus)/

Institute of Food and Agriculture, 116 Avenham Drive, DeLand, FL 32724

\author{
Wendy Mussoline \\ Flagler County Extension Center, University of Florida/Institute of Food and \\ Agriculture, 150 Sawgrass Road, Bunnell, FL 32110
}

Additional index words. heat stress, muck soils, breeding, alternative crops, genotype $\times$ environment interaction

\begin{abstract}
Lettuce (Lactuca sativa L.) is planted in Florida starting late fall at the end of September and continuing through the last harvest in May. In recent years, the season has shortened because of warm temperatures and weather-related events, such as rainfall at the beginning and the end of the season. During the transition between summer production in the Western U.S. lettuce season and the beginning of Florida's winter production, there may be shortages of lettuce and other leafy vegetables in U.S. East Coast markets. In this research, we evaluated a set of lettuce breeding lines and cultivars in both sand and muck soils and a subset of romaine lettuces to determine whether lettuce planted in Florida's sandy soils could help meet the supply shortage in the delay between the Western and Eastern U.S. lettuce seasons. Significant genetic variation and genotype $\times$ environment $(G \times E)$ interactions were observed among lettuce genotypes when planted in both sand and muck soils, suggesting that lettuce cultivars should be adapted and bred specifically for sandy soils. Romaine and butterhead lettuce lines produced higher yield in sandy soils; a particular romaine breeding line (BG18-0588) had good yield and less heat-related disorders when planted in warmer temperatures. Producing lettuce in sandy soils may have a higher production cost because of additional specific practices such as transplant production, plastic mulch, and fertigation, but these costs may be offset by increased productivity due to better weed control and nutrient timing. However, a future analysis should be conducted to elucidate the economic feasibility of producing lettuce in sandy soils.
\end{abstract}

\footnotetext{
Received for publication 10 Sept. 2020. Accepted for publication 1 Nov. 2020.

Published online 4 December 2020

We acknowledge the Hatch Project FLA-EREC005599. The Plant Breeding Graduate Initiative from the Plant Breeding Working Group and the Dean of Research Office of the University of Florida/Institute of Food and Agriculture. Additional funding for this work was provided by the St. Johns Board of County Commissioners. We thank Amanda Carroll and Heriberto Trevino for their help with experiments and seed increasing at the Everglades Research and Education Center and to Scott Chambers at the Hastings Agricultural Extension Center. We acknowledge Dennis Calvin Odero and Jesse Murray for the internal review and valuable feedback to this manuscript.

G.V.S. is the corresponding author. E-mail: gsandoyamiranda@ufl.edu.

This is an open access article distributed under the CC BY-NC-ND license (https://creativecommons. org/licenses/by-nc-nd/4.0/).
}

Lettuce (Lactuca sativa L.) is one of the most valuable vegetables in the world. The United States ranks as the second largest lettuce producer after China, harvesting $\approx 105,000$ ha worth $\$ 3.5$ billion in 2019 [Food and Agriculture Organization of the United Nations, 2020; U.S.Department of Agriculture National Agricultural Statistics Service Information (USDA NASS), 2019]. Florida accounts for $\approx 3.5 \%$ of the U.S. total lettuce production, corresponding to $\approx 3700$ harvested ha (USDA NASS, 2019). Most of this production is concentrated in the Everglades Agricultural Area (EAA) (Sandoya and $\mathrm{Lu}, 2020$ ), where lettuce is planted as a rotational crop between sugarcane (Saccharum spp. interspecific hybrids) cycles (Castillo and Wright, 2008).

The EAA is an artificially drained area $(283,300 \mathrm{ha})$ renowned for tremendous agricultural productivity. Soils in the EAA, often called "muck" (Histosols), contain high organic matter (OM) (typically $65 \%$ to $85 \%$
OM by dry weight) and ample supply of nutrients (Janardhanan and Daroub, 2010; Wright and Hanlon, 2019). Despite great fertility, these soils are constantly subjected to wind erosion and $\mathrm{OM}$ decomposition by microorganisms (Bhadha et al., 2020; Rodriguez et al., 2020) and have a large seedbank of problematic weed species (Cantliffe and Karchi, 1992; Odero and Wright, 2013; Robles et al., 1997).

Warmer temperatures affect the lettuce crop in muck soils. Historically, lettuce production in the EAA started with the first plantings in September and ended in May with the last harvests. Currently, the warmer temperatures experienced in the EAA have shortened the lettuce season to planting in late September and harvesting between midMarch to the beginning of April. In the future, growers may need to plant lettuce earlier in the season in northern and central Florida because northern latitudes present cooler temperatures than those observed in the EAA. The expansion of lettuce cultivation into northern Florida regions has the potential to extend the growing season and allow producers to supply lettuce to the market during shortages (Cantliffe and Karchi, 1992). However, soils in northern regions contain much higher sand content and may require adapted lettuce cultivars. Current lettuce cultivars planted in Florida have been specifically bred for muck soils since lettuce production mainly occurs in the EAA.

Soils found in central and northern Florida are derived from sandy marine sediments and, therefore, present sandy texture (Mylavarapu et al., 2019). Florida's sandy soils are acidic and highly weathered, as a result of high temperatures and abundant rainfall characteristic to these regions. Several agricultural commodities are planted in Florida's sandy soils including potato, cabbage, watermelon, melon, tomato, squash, sweet corn, strawberry, and bell pepper (Freeman et al., 2019). Lettuce is not currently planted in sandy soils but may serve as a potential early crop for growers located in central and northern areas of Florida, where sandy soils predominate.

Planting lettuce in sandy soils earlier than when planting begins in muck soils will have the risk of facing warmer temperatures. Therefore, lettuce yield may be negatively affected by less marketable heads, the presence of bolted plants, and the appearance of disorders such as tipburn (Jenni et al., 2013). Bolting is a process in which the lettuce stem elongates after the transition from vegetative to reproductive stage that negatively affects lettuce marketability and is strongly influenced by environmental factors, such as temperature and photoperiod, as well as genetic variation (Hao et al., 2018). Tipburn is a physiological disorder commonly associated with localized calcium deficiency and leaf margin necrosis that occur in newly formed leaves and is exacerbated by warm temperatures and high relative humidity that inhibits calcium translocation from evapotranspiration (Barta and Tibbits, 2000; Jenni et al., 2013). 
One limitation for planting lettuce in sandy soils is the need of using transplants because earlier direct plantings in Florida may not be possible due to warmer soil conditions. Although transplanting may increase the cost of production, this expense might be offset by the benefits associated with using plastic mulch and drip fertigation required for production in sandy soils. Both help reduce weed pressure (Birthisel et al., 2019; Cantliffe et al., 1997), result in more efficient application of water and fertilizer (Alkhader et al., 2019), increase soil moisture near rhizosphere areas (Mkhabela et al., 2019), and permit more efficient control of soilborne pathogens (dos Santos et al., 2014).

Lettuce is widely planted in different soil types and in soilless systems; however, there is limited information on lettuce production in sandy soils of Florida. In this research, we studied the adaptability of lettuce to sandy soils using a group of cultivars and breeding lines with no prior testing in Florida's sandy soils. As some lettuce lines performed better in sand, we investigated whether selection conducted in muck soils would be effective in sandy soils by determining the $\mathrm{G} \times \mathrm{E}$ interactions. Lastly, we subjected four selected romaine lines to early-season plantings with the goal of evaluating whether the current lettuce production window has the potential to be lengthened by planting in cooler northern regions with sandy soils.

\section{Materials and Methods}

\section{Initial assessment of lettuce cultivars and} breeding lines in sandy vs. muck soils

Plant material. Twenty-six lettuce cultivars and breeding lines, consisting of $11 \mathrm{cos}$ (romaine), 10 iceberg (crisphead), 4 butterhead, and 1 green leaf, were used in an initial assessment conducted in four individual experiments (Table 1). In this initial assessment, 11 accessions were experimental breeding lines defined as the breeding base of the University of Florida's Institute of Food and Agriculture Sciences (UF/IFAS) Lettuce Breeding Program and are named with numbers. Eleven were commercial cultivars with formal names that are currently used by growers at the EAA, and the other four were cultivars developed by the UF/ IFAS lettuce breeding program that were previously used as commercial cultivars.

Sandy soil experiments. The first two experiments (Expts. 1 and 2) were conducted on sandy soils in commercial production fields in 2017 and 2018 in Loxahatchee, FL (Table 2). Lettuce seeds were germinated at the UF/IFAS Everglades Research and Education Center (EREC) in 242-cell seedling trays filled with commercial substrate (Sun Gro Horticulture Professional Growing Mix; Sun Gro Horticultural Products, Bellevue, WA). Seedlings, which were sown on 6 Dec. 2017 for Expt. 1 and on 27 Sept. 2018 for Expt. 2, were grown for 5 to 6 weeks before transplanting in $1.14 \mathrm{~m} \times 178.30 \mathrm{~m}$ beds covered with white polyethylene mulch. Seedlings were transplanted in Riviera fine sand (loamy, siliceous, active, hyperthermic Arenic Glossaqualfs) on 19 Jan. 2018 for Expt. 1 and in Holopaw fine sand (loamy, siliceous, active, hyperthermic Grossarenic Endoaqualfs) on 6 Nov. 2018 for Expt. 2 on a 4-row bed layout. Each plot was $4.57 \mathrm{~m}$ long and consisted of a cultivar/line planted in two rows with a $0.20 \mathrm{~m}$ spacing between rows and a $0.30 \mathrm{~m}$ spacing between plants (except in the first experiment where spacing between plants was $0.15 \mathrm{~m}$ ). Pest and disease management were applied according to the industry standards and fertigation was supplied via two drip lines.

Muck soil experiments. Two field experiments (Expts. 3 and 4) were planted on muck soils on 23 Oct. 2018 and on 5 Mar. 2019, respectively (Table 2). The trial in 2018 was established on Dania muck (euic, hyperthermic Lithic Haplosaprists) at the EREC, in Belle Glade, FL. Field fertilization consisted of a preplanting application of $560 \mathrm{~kg} \cdot \mathrm{ha}^{-1}$ of ammonium polyphosphate $(11 \mathrm{~N}-16.2 \mathrm{P}-0 \mathrm{~K}$; Wedgworth's Inc., Clewiston, FL) plus two post-planting split applications of $4.5 \mathrm{~kg} \cdot \mathrm{ha}^{-1}$ of multipurpose fertilizer $(20 \mathrm{~N}-8.7 \mathrm{P}-16.6 \mathrm{~K}$; Plant Foods Inc., Vero Beach, FL), following soil test recommendations for lettuce crops from the UF/IFAS Soil Testing Laboratory at the EREC. Pests and diseases were managed following the industry standard recommendations of the Vegetable Production Handbook of Florida (Kanissery et al., 2019), and irrigation was provided as needed throughout the crop cycle using a combination of overhead (establishment) and seepage (afterward) irrigation. The trial in 2019 was performed on Terra Ceia muck (euic, hyperthermic Lithic Haplosaprists) in a commercial leafy production field located near Belle Glade, FL. Field fertilization, weed management, and irrigation were performed following the standard procedures adopted by the commercial farm. Both experiments were direct seeded on 0.15$\mathrm{m}$ raised beds. Plots consisted of two rows per cultivar/line and were $6.1 \mathrm{~m}$ long. At the fourleaf stage, seedlings were thinned to a $0.30 \mathrm{~m}$ in-row spacing.

\section{Additional screening of romaine lettuce in North Florida sandy soils for earlier planting}

Plant material. Three romaine lettuce breeding lines from the UF/IFAS Lettuce Breeding Program and one romaine cultivar were tested in subsequent experiments;

Table 1. Breeding lines and cultivars selected for experiments in muck and sandy soils, morphological types (butterhead, iceberg, leaf, and romaine), breeding status, and breeder.

\begin{tabular}{|c|c|c|c|}
\hline Breeding line/cultivar & Type & Status & Breeder \\
\hline \multicolumn{4}{|l|}{ Initial assessment } \\
\hline 60176 & Butterhead & Breeding line & UF/IFAS \\
\hline 60178 & Butterhead & Breeding line & UF/IFAS \\
\hline Floribibb $^{z}$ & Butterhead & Cultivar & UF/IFAS \\
\hline Palmetto $^{y}$ & Butterhead & Cultivar & Private company \\
\hline 60167 & Iceberg & Breeding line & UF/IFAS \\
\hline 60168 & Iceberg & Breeding line & UF/IFAS \\
\hline 60171 & Iceberg & Breeding line & UF/IFAS \\
\hline 60172 & Iceberg & Breeding line & UF/IFAS \\
\hline 60180 & Iceberg & Breeding line & UF/IFAS \\
\hline Belle Glade ${ }^{y}$ & Iceberg & Cultivar & Private company \\
\hline Chosen $^{\mathrm{y}}$ & Iceberg & Cultivar & Private company \\
\hline Flagler $^{\mathrm{y}}$ & Iceberg & Cultivar & Private company \\
\hline Floricrisp $1265^{z}$ & Iceberg & Cultivar & UF/IFAS \\
\hline Lantana $^{\mathrm{y}}$ & Iceberg & Cultivar & Private company \\
\hline $\operatorname{RSX} 743^{y}$ & Leaf & Breeding line & Private Company \\
\hline 60166 & Romaine & Breeding line & UF/IFAS \\
\hline 60182 & Romaine & Breeding line & UF/IFAS \\
\hline 60184 & Romaine & Breeding line & UF/IFAS \\
\hline 70096 & Romaine & Breeding line & UF/IFAS \\
\hline Floricos $83^{z}$ & Romaine & Cultivar & UF/IFAS \\
\hline Hialeah $^{y}$ & Romaine & Cultivar & Private company \\
\hline Homestead $^{\mathrm{y}}$ & Romaine & Cultivar & Private company \\
\hline Manatee $^{y}$ & Romaine & Cultivar & Private company \\
\hline Okeechobee $^{y}$ & Romaine & Cultivar & Private company \\
\hline Sawgrass $^{\mathrm{y}}$ & Romaine & Cultivar & Private company \\
\hline Terrapin $^{z}$ & Romaine & Cultivar & UF/IFAS \\
\hline \multicolumn{4}{|l|}{ Follow-up experiments } \\
\hline 60182 & Romaine & Breeding line & UF/IFAS \\
\hline 70096 & Romaine & Breeding line & UF/IFAS \\
\hline BG18-0588 & Romaine & Breeding line & UF/IFAS \\
\hline Terrapin $^{z}$ & Romaine & Cultivar & UF/IFAS \\
\hline
\end{tabular}

${ }^{\mathrm{z}}$ Lettuce cultivars developed by the University of Florida/Institute for Food and Agricultural Services (UF/ IFAS) lettuce breeding program (Guzman and Raleigh, 1984; Guzman and Zitter, 1983, 1984; Sandoya and $\mathrm{Lu}, 2020)$. Cultivar Terrapin is currently under Plant Variety Protection.

${ }^{\mathrm{y}}$ Commercial lettuce cultivars currently used by growers in Florida and developed by private seed companies.

${ }^{\mathrm{x}}$ Modern advanced breeding line currently in development by UF/IFAS lettuce breeding program. 
romaine lettuce was chosen based on their overall yield in sandy soils in the previous trials. This group included 'Terrapin' and breeding line 60182, which had a better performance in the initial assessment; the breeding line 70096 that had an equal performance in muck and sandy soils; and an experimental line BG18-0588 (Belle Glade 2018 line 588) was included because it has been previously observed to perform well in warmer environments with little tipburn (G. Sandoya, personal observations) (Table 1).

Experiment description. In 2019, two experiments were conducted at the UF/IFAS Hastings Agricultural Extension Center in Hastings, FL (located $\approx 350 \mathrm{~km}$ north of the EAA), to test the performance of the four romaine accessions in early season planting experiments on sandy soils (Table 2). The soil at the experimental sites was Ellzey fine sand (sandy, siliceous, hyperthermic Arenic Endoaqualfs). Seedlings of each genotype were produced by Speedling Inc. at two different nursery locations (Sun City, FL, and Blairsville, GA) to test the effect of temperature differences during seedling establishment. Seeds of romaine lettuce were sown in both nurseries on 15 Aug. 2019 for the first experiment (E5) and on 26 Aug. 2019 for the second experiment (E6). Seedlings from the two nurseries were grown for 3 weeks before being manually transplanted into white polyethylene mulch beds on 11 Sept. 2019 and 1 Oct. 2019 for E5 and E6, respectively (Table 2 ).

Each treatment was defined as the combination of one breeding line and one seed- ling source. Each plot consisted of a 4-row plastic mulched bed $(1.22 \mathrm{~m}$ wide and $10 \mathrm{~m}$ long) containing two drip lines for nutrient and water application via fertigation. In each experiment, field fertilization consisted of a preplanting application of $1400 \mathrm{~kg} \cdot \mathrm{ha}^{-1}$ of fertilizer $(4 \mathrm{~N}-3.5 \mathrm{P}-3.3 \mathrm{~K})$. In the first experiment, fertigation was initiated $6 \mathrm{~d}$ after the lettuce seedlings were transplanted and continued for 6 weeks, with one application occurring each week. In the second experiment, the first fertigation occurred $1 \mathrm{~d}$ before transplanting and continued for another 6 weeks with one application per week. In both trials, each fertigation event comprised the application of $28 \mathrm{~kg} \cdot \mathrm{ha}^{-1}$ of $\mathrm{N}$ and 23.2 $\mathrm{kg} \cdot \mathrm{ha}^{-1}$ of $\mathrm{K}$ using a liquid fertilizer blend $(8 \mathrm{~N}-0 \mathrm{P}-6.6 \mathrm{~K})$. In total, each experiment received $224 \mathrm{~kg} \cdot \mathrm{ha}^{-1}$ of $\mathrm{N}, 48.9 \mathrm{~kg} \cdot \mathrm{ha}^{-1}$ of $\mathrm{P}$, and $185.9 \mathrm{~kg} \cdot \mathrm{ha}^{-1}$ of $\mathrm{K}$ on pre- and postplanting applications. Irrigation was provided three times/day for $10 \mathrm{~min}$ each event using two drip lines with a $30 \mathrm{~cm}$ emitter spacing and $\mathrm{a} \approx 45 \mathrm{~L} \cdot \mathrm{h}^{-1}$ output. Under rainfall events of more than $12 \mathrm{~mm}$, the irrigation was interrupted for $1 \mathrm{~d}$.

Data collection. In all six trials, plants were evaluated by lettuce type at harvest maturity, which varied from 57 to $79 \mathrm{~d}$ after sowing, based on the maturity of controls that included cultivars Palmetto for butterhead, Chosen for iceberg, and Hialeah or Okeechobee for romaine in Expts. 1 through 4 and Terrapin for romaine in Expts. 5 and 6. In Expts. 1 through 4, harvest started with leaf types butterhead and romaine and was followed by iceberg 1 week later (Table 2). Four traits were measured during the execution of these experiments: head weight (HW) was measured on 10 randomly harvested lettuce heads per plot and expressed as grams per head; marketability was estimated by counting the number of total plants per plot and the number of heads as the percentage of lettuce heads that would meet market requirements, such as expected head formation, uniformity and heads free of visual diseases and disorders; tipburn incidence was recorded post-harvest by slicing 10 heads in half to observe the inner whorl; and bolting incidence was estimated by counting the total number of plants in each plot that presented stem elongation.

Experimental design and statistical analysis. Expts. 1 through 4 were arranged following a randomized complete block design (RCBD) with three replications. Statistical analyses were calculated using the GLIMMIX procedure in SAS software, Version 9.4 (SAS Institute Inc., Cary, NC). The HW, tipburn, and marketability data were grouped according to each lettuce type before being subjected to analysis of variance (ANOVA). Due to the absence of bolting in most lettuce accessions grown in muck soil experiments, bolting data were not analyzed. The factors soil, genotype, and soil $\times$ genotype interaction were considered fixed effects, whereas block nested within experiment was considered as random effect. Since the leaf type was represented by a single cultivar, soil was the only fixed effect used in the respective model.

Expts. 5 and 6 conducted in Hastings, FL, followed a RCBD with three replications. HW and bolting data of all four romaine

Table 2. Number, location, soil type, number of cultivars/breeding lines tested, and planting date conducted in this research.

\begin{tabular}{lllcccc}
\hline Expt. & Location & Soil type & Cultivars/breeding lines & Sowing & Transplanting & Harvest \\
\hline Initial assessment & & & & & & \\
Sand 2017 & Loxahatchee & Sand & 26 & 6 Dec. 2017 & 19 Jan. 2018 & 23 Feb. 2018z \\
Sand 2018 & Loxahatchee & Sand & 26 & 27 Sept. 2018 & 6 Nov. 2018 & 5 Dec. 2018 \\
Muck 2018 & Belle Glade & Muck & 26 & 23 Oct. 2018 & 2 & 28 Dec. 2018 \\
Muck 2019 & Belle Glade & Muck & 26 & 5 Mar. 2019 & 3 \\
Early planting & & & & & 1 May 2019z \\
Sand 2019 & Hastings & Sand & 4 & 15 Aug. 2019 & 11 Sept. 2019 & 29 Oct. 2019 \\
Sand 2019 & Hastings & Sand & 4 & 26 Aug. 2019 & 1 Oct. 2019 & 4 Nov. 2019 \\
\hline
\end{tabular}

${ }^{\mathrm{z}}$ Actual date for harvest of butterhead, leaf and romaine lettuce; iceberg harvesting occurred $\approx 1$ week later.

Table 3. Analysis of variance of head weight, marketability and tipburn of 26 lettuce cultivars and breeding lines planted in two experiments in sandy soils (Expts. 1 and 2) and two experiments in muck soils (Expts. 3 and 4) near Loxahatchee and Belle Glade, FL.

\begin{tabular}{|c|c|c|c|c|c|c|c|c|c|c|c|c|}
\hline \multirow[b]{2}{*}{ Source of variation } & \multicolumn{4}{|c|}{ Head wt } & \multicolumn{4}{|c|}{ Marketability } & \multicolumn{4}{|c|}{ Tipburn } \\
\hline & $\mathrm{df}_{\text {num }}{ }^{\mathrm{y}}$ & $\mathrm{df}_{\mathrm{den}^{\mathrm{y}}}$ & F value & $P$ value & $\mathrm{df}_{\text {num }}$ & $\mathrm{df}_{\mathrm{den}}$ & F value & $P$ value & $\overline{d f_{\text {num }}}$ & $\mathrm{df}_{\mathrm{den}}$ & F value & $P$ value \\
\hline Butterhead & 1 & 10.05 & 6.21 & 0.0318 & 1 & 7 & 0.00 & 0.9974 & 1 & 10 & 15.50 & 0.0028 \\
\hline Iceberg & 1 & 10.02 & 5.62 & 0.0392 & 1 & 7.069 & 85.42 & $<0.0001$ & 1 & 10 & 4.77 & 0.0539 \\
\hline Romaine & 1 & 10.40 & 0.40 & 0.5396 & 1 & 7.707 & 15.37 & 0.0056 & 1 & 10 & 16.15 & 0.0024 \\
\hline Genotype & 25 & 239.2 & 5.84 & $<0.0001$ & 25 & 166.1 & 4.90 & $<0.0001$ & 25 & 239.6 & 3.61 & $<0.0001$ \\
\hline Butterhead & 3 & 29.17 & 10.01 & 0.0001 & 3 & 21 & 8.90 & 0.0005 & 3 & 30 & 2.31 & 0.0962 \\
\hline Genotype $\times$ soil & 25 & 239.2 & 4.55 & $<0.0001$ & 25 & 166.1 & 3.63 & $<0.0001$ & 25 & 239.6 & 3.17 & $<0.0001$ \\
\hline Butterhead $\times$ soil & 3 & 29.17 & 11.86 & $<0.0001$ & 3 & 21 & 2.97 & 0.0553 & 3 & 30 & 2.31 & 0.0962 \\
\hline Iceberg $\times$ soil & 9 & 89.03 & 2.96 & 0.0040 & 9 & 60.58 & 1.69 & 0.1121 & 9 & 89 & 0.5 & 0.8740 \\
\hline Romaine $\times$ soil & 10 & 92.72 & 3.78 & 0.0003 & 10 & 68.11 & 2.49 & 0.0099 & 9 & 85 & 0.53 & 0.8463 \\
\hline
\end{tabular}

${ }^{\mathrm{z}}$ Differences among genotypes and the interaction with soil factor was not calculated for leaf type as only one cultivar was used during the execution of this experiment.

${ }^{\mathrm{y}} \mathrm{df}_{\text {num }}$ is the degree of freedom of numerator, $\mathrm{df}_{\mathrm{den}}$ is the degree of freedom of denominator. 
accessions were subjected to ANOVA using the GLIMMIX procedure in SAS software. The factors genotype, nursery, and experiment and all possible interactions were considered as fixed effects, whereas block nested within experiment was considered as random effect.

In all experiments, least square means of each treatment and $95 \%$ confidence intervals (CIs) were generated using the lsmeans statement in PROC GLIMMIX. Significant differences between treatments were obtained using Fisher's least significant difference test at a level of significance of $P<0.05$ using the PDMIX800 macro (Saxton, 1998).

$G \times E$ analysis. A $\mathrm{G} \times \mathrm{E}$ analysis was conducted to assess the HW variability of lettuce cultivars and lines across different environments and soil types. Each environment was defined as the combination of a location and a year. The HW of lettuce genotypes were subjected to ANOVA to estimate the effects of genotype, environment, and $\mathrm{G} \times \mathrm{E}$ using the GGEbiplot software (http://www.ggebiplot. com/). The GGE biplots were constructed following the equation presented by Yan et al. (2000):

$$
Y_{i j}-\mu-\beta_{j}=\lambda_{1} \xi_{i 1} \eta_{j 1}+\lambda_{2} \xi_{i 2} \eta_{j 2}+\varepsilon_{i j},
$$

where $Y_{i j}$ is the mean for the $i^{\text {th }}$ genotype in the $j^{\text {th }}$ environment, $\mu$ is the grand mean $\beta_{j}$ is the main effect of environment $j, \lambda_{1}$ and $\lambda_{2}$ are the singular values of the first and second principal components, $\xi_{i 1}$ and $\xi_{j 2}$ are the PC1 and PC2 scores, respectively, for genotype $i^{\text {th }}$, $\eta_{j 1}$ and $\eta_{j 2}$ are the eigenvectors for the $j^{\text {th }}$ environment for $\mathrm{PC} 1$ and $\mathrm{PC} 2$, and $\varepsilon_{i j}$ is the residual error term.

\section{Results and Discussion}

Horticultural characteristic in lettuce planted in muck versus sandy soils. The yield of lettuce planted in sandy soils was statistically the same as in muck soils $(P=0.2617)$, as expressed by HW (Table 3). A small difference in HW is noted between sandy and muck soils (Fig. 1), however, HW was clearly affected by experiment. Temperature is unlikely responsible for these differences because temperatures were similar during the execution of the experiments; maximum/ minimum temperatures varied from $26{ }^{\circ} \mathrm{C} /$ $15{ }^{\circ} \mathrm{C}$ to $29{ }^{\circ} \mathrm{C} / 16{ }^{\circ} \mathrm{C}$ (Table 4). These temperatures were near the acceptable range for lettuce production because lettuce is well adapted to temperatures between 18 to $25^{\circ} \mathrm{C}$ during daytime and 10 to $15^{\circ} \mathrm{C}$ at nighttime (Hayes, 2018). Instead, other factors likely influenced the differences found in the overall HW for these four experiments. Muck experiments were planted at two locations; the first muck experiment was planted in an experimental farm at the EREC, and the second was planted in a commercial field located in the EAA. Although both locations are nearby, commercial fields have better crop management practices including a more efficient weed control and fertilization that may have influenced HW.

HW in lettuce varied among morphological types with respect to soil types. In butterhead

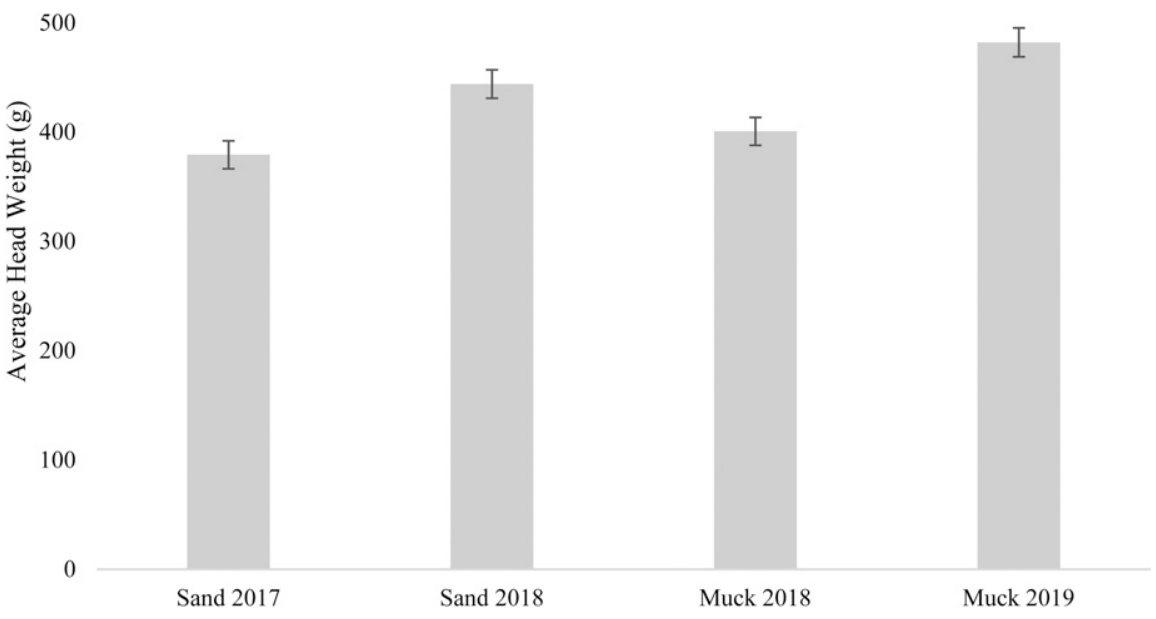

Fig. 1. Least square Means (LSM) of head weight (HW) averaged by experiment regardless of lettuce type in four experiments conducted between 2017 and 2019 in two soil types, muck and sand near Loxahatchee (sand) and Belle Glade (muck), FL. Least significant differences are presented by experiment $(\mathrm{LSD}=39.2 ; P=0.05)$.

Table 4. Monthly average of medium, minimum, and maximum temperature and total monthly precipitation during the execution of experiments in this research in Loxahatchee, Belle Glade, and Sun City, FL, and in Blairsville, GA.

\begin{tabular}{|c|c|c|c|c|c|c|c|}
\hline \multirow[b]{2}{*}{ Location } & \multirow[b]{2}{*}{ Yr } & \multirow[b]{2}{*}{ Expt. } & \multirow[b]{2}{*}{ Month } & \multicolumn{3}{|c|}{ Temperature $\left({ }^{\circ} \mathrm{C}\right)$} & \multirow{2}{*}{$\begin{array}{l}\text { Precipitation } \\
\text { (mm) }\end{array}$} \\
\hline & & & & Medium & Min & $\overline{\operatorname{Max}}$ & \\
\hline \multirow[t]{4}{*}{ Loxahatchee, FL } & 2018 & 1 & January & 18 & 13 & 23 & 33.27 \\
\hline & & 1 & February & 23 & 18 & 29 & 12.19 \\
\hline & & 2 & November & 23 & 18 & 29 & 26.92 \\
\hline & & 2 & December & 20 & 15 & 26 & 23.88 \\
\hline \multirow[t]{10}{*}{ Belle Glade, FL } & 2017 & 1 & December & 18 & 12 & 26 & 43.43 \\
\hline & 2018 & 1 & January & 16 & 11 & 23 & 18.80 \\
\hline & & - & February & 21 & 15 & 29 & 6.10 \\
\hline & & 2 & September & 26 & 22 & 33 & 128.02 \\
\hline & & 2 and 3 & October & 25 & 20 & 32 & 19.56 \\
\hline & & 2 and 3 & November & 22 & 16 & 28 & 44.70 \\
\hline & & 3 & December & 19 & 13 & 26 & 34.29 \\
\hline & 2019 & 4 & March & 21 & 15 & 28 & 34.04 \\
\hline & & 4 & April & 23 & 17 & 30 & 39.37 \\
\hline & & 4 & May & 25 & 20 & 32 & 122.17 \\
\hline \multirow[t]{2}{*}{ Blairsville, GA } & 2019 & 5 and 6 & August & 24 & 17 & 30 & 94.74 \\
\hline & & 5 and 6 & September & 23 & 15 & 31 & 8.38 \\
\hline \multirow[t]{2}{*}{ Sun City, FL } & 2019 & 5 and 6 & August & 27 & 23 & 33 & 243.84 \\
\hline & & 5 and 6 & September & 27 & 22 & 33 & 31.50 \\
\hline \multirow[t]{4}{*}{ Hastings, FL } & 2019 & - & August & 27 & 23 & 33 & 139.95 \\
\hline & & 5 & September & 26 & 21 & 32 & 110.24 \\
\hline & & 5 and 6 & October & 24 & 20 & 29 & 105.41 \\
\hline & & 6 & November & 17 & 11 & 23 & 83.06 \\
\hline
\end{tabular}

${ }^{\mathrm{z}}$ Weather data collected from the closest Florida Automated Weather Network station, located in Balm, FL $(\approx 25 \mathrm{~km}$ from the nursery in Sun City, FL).

lettuce, significant differences $(P=0.0318)$ were found for HW between muck and sand plantings (Table 3; Fig. 2). Romaine and leaf lettuce showed a slightly higher HW in sand compared with muck soils, but these differences were found to be nonsignificant $(P=$ 0.5396 and $P=0.3433$, respectively) (Table 3; Fig. 2). The results of this research indicate that lettuce, specifically romaine and butterhead types, can be planted in sandy soils if an adequate fertilizer program, irrigation, and practices that might include the use of microorganisms as biostimulants are used. A proper fertilization program along with the application of biostimulants may improve the yield of lettuce grown in sandy soils up to $85 \%$, as 
previously observed in Brazil (Moraes et al., 2018).

Furthermore, the findings of this study are consistent with lettuce's ubiquitous adaptation, ranging from clay soils in Western United States, to soilless systems in protected structures (hydroponic, aeroponic, aquaponic), and more specifically adapted to muck soils in Florida's subtropical EAA since the 1940s (Parkell et al., 2015; Sandoya, 2019; Sandoya and Lu, 2020). Breeding lines and cultivars tested in this research were improved for this latter environment, which inherently demonstrates their adaptability to warmer environments with unique soil properties (Guzman and Raleigh, 1984; Guzman and Zitter, 1983, 1984; Mikel, 2013). In fact, several releases from the UF/IFAS lettuce breeding program, including iceberg cultivars South Bay, Raleigh, Floricrisp 1265, and Floricrisp 1366; and romaine cultivars Tall Guzmaine, and Floricos 83 (Guzman, 1984, 1986; Guzman and Raleigh, 1984; Guzman and Zitter, 1983; Sandoya and Lu, 2020), are planted in soils other than muck and have been adapted to several geographic locations, soil types, and production systems (Dufault et al., 2009; Mikel, 2013; Simko, 2019; Soundy et al., 2005). Therefore, it is not surprising that the crop may also be cultivated in sandy soils despite low fertility, because adding adequate fertilizers to the lettuce crop has proven to successfully yield good marketable heads in greenhouse lettuce production (Sabat et al., 2015; Wiggins et al., 2020).

In addition, we evaluated genotypes for differences in HW within each lettuce type across both sandy and muck environments. Romaine $(P<0.0001)$ and butterhead $(P=$ $0.0001)$ both had significant differences in genotype performance for HW when cultivated in the two soil types (Fig. 3; Table 3). Overall, lettuce cultivation in sandy soils resulted in a superior and significant HW compared with muck soils in several butterhead and romaine lettuce lines and cultivars (Fig. 4). For example, in butterhead lettuce, the breeding line 60176 and UF/IFAS cultivar Floribibb had higher HW in sand compared with muck. Regarding romaine types, the formerly released UF/IFAS cultivar, Floricos 83, and commercial cultivar Hialeah had a significantly higher HW in sandy soils compared with muck soils, whereas the UF/ IFAS cultivar Terrapin and breeding line 70096 had a similar HW in both soil types. Other cultivars and breeding lines had a higher and nonsignificant HW in muck soil plantings (Fig. 4). The genetic variation within these UF/IFAS butterhead and romaine cultivars and breeding lines could be considered as the parental material for potential improvement programs targeted for sandy soils.

The practice of planting iceberg lettuce in Florida's sandy soils has previously proven successful (Cantliffe and Karchi, 1992; Cantliffe et al., 1997). However, in this research, iceberg lettuce HW was significantly higher in muck soils compared with sand $(P=$

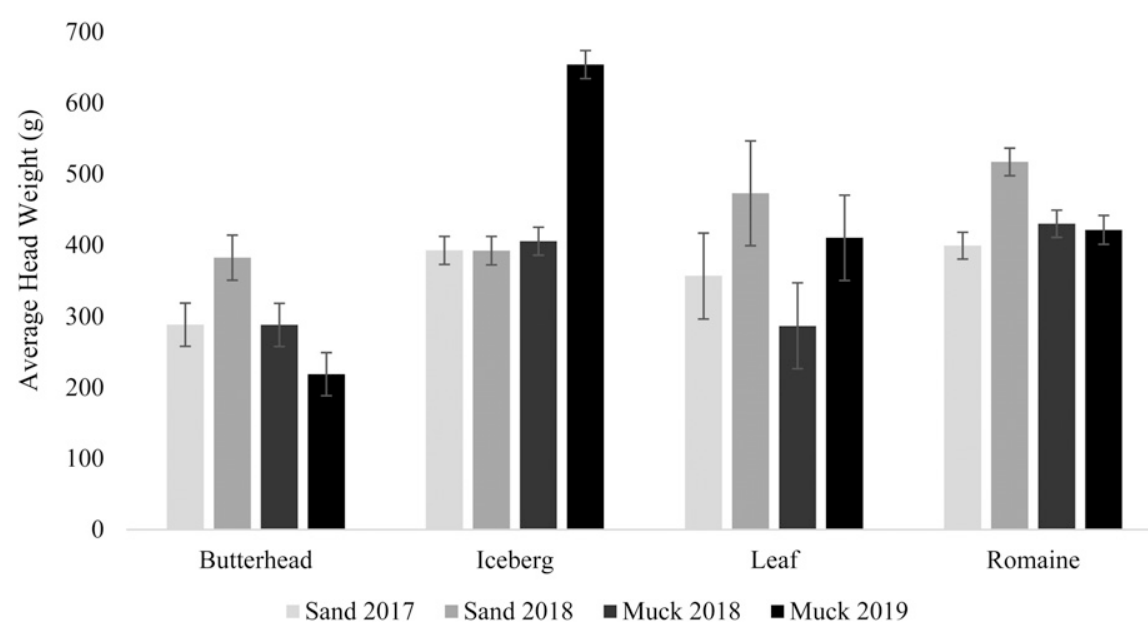

Fig. 2. Least square means (LSM) of head weight (HW) averaged by lettuce type in four experiments conducted between 2017 and 2019 in two soil types, muck and sand near Loxahatchee (sand) and Belle Glade (muck), FL. Least significant differences (LSD; $P=0.05$ ) are presented for each type and experiment; butterhead $(\mathrm{LSD}=94.4)$, iceberg $(\mathrm{LSD}=151.5)$, leaf $(\mathrm{LSD}=163.1)$, and romaine $(\mathrm{LSD}=$ 130.3).

$$
700
$$

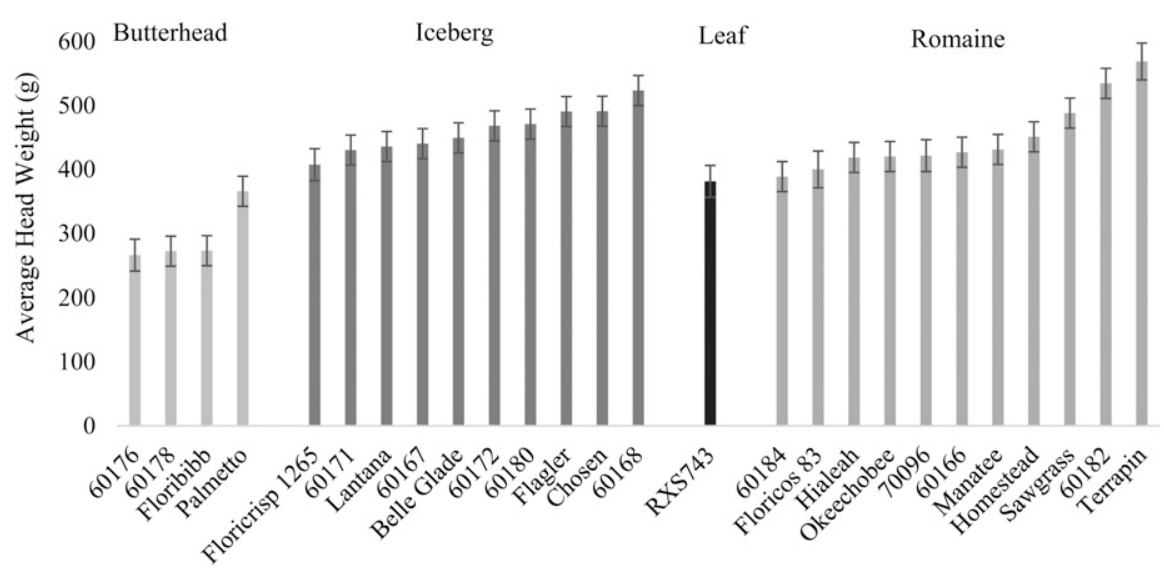

Fig. 3. Least square means (LSM) of head weight (HW) averaged by lettuce cultivars in four experiments conducted between 2017 and 2019 in two soil types, muck and sand near Loxahatchee (sand) and Belle Glade (muck), FL. Least significant difference (LSD; $P=0.05$ ) is presented for cultivar or breeding line $(\mathrm{LSD}=86.21)$.

0.0392; Table 3) which is reflected in almost all the tested genotypes (Figs. 4 and 5). This difference might be due to differences in fertility requirements among the different lettuce types (Hochmuth et al., 2018). Iceberg lettuces tend to require higher amounts of zinc $(\mathrm{Zn})$ and manganese $(\mathrm{Mn})$ than romaine and butterhead types to maintain adequate fertility. Several studies have documented increases in dry mass of iceberg lettuce in response to the application of $\mathrm{Zn}$ and $\mathrm{Mn}$ to the crop (de Resende et al., 2005, 2008; Petrazzini et al., 2010; Yuri et al., 2006), or a decrease in dry mass of iceberg lettuce compared with leaf lettuce when grown in nutrient solutions containing suboptimal levels of $\mathrm{Zn}$ and Mn (Roosta et al., 2018).
Coincidently, the relatively high $\mathrm{pH}$ (between 7.0 and 8.0) of EAA's muck soils tends to have a high binding affinity for trace elements, such as $\mathrm{Zn}$ and $\mathrm{Mn}$, the bioavailability of which are often found in very low concentrations in soil solution (Hochmuth et al., 2018). Lettuce farmers tend to have well-established programs of foliar fertilization with the goal of supplying macro- and micronutrients throughout the crop cycles to compensate the low bioavailability of $\mathrm{Zn}$ and $\mathrm{Mn}$. A complementary application of foliar fertilizers based on $\mathrm{Zn}$ and Mn may help explain the overall higher HW of iceberg lettuce in fertilized muck soils, and especially the higher iceberg HW in E4 conducted in a commercial production system. This 
experiment was conducted on a commercial farm that continuously produces lettuce for at least 3 years, whereas E3 received no micronutrient applications during the experiment.

In this research, differences were identified between sandy and muck soils $(P=$ $0.0008)$ and within the germplasm tested $(P<0.0001)$ for the percentage of marketable heads (Table 3 ). These differences were notable within each type and most accessions had higher percentage of marketable heads when planted in sandy soils compared with muck (Table 5), which agrees with the previous report by White and Guzman (1979). Higher lettuce marketability grown in sandy soils may be associated with better growing conditions provided by the plastic mulching, including greater soil moisture retention, lower weed pressure, and localized and more frequent application of fertilizers and water

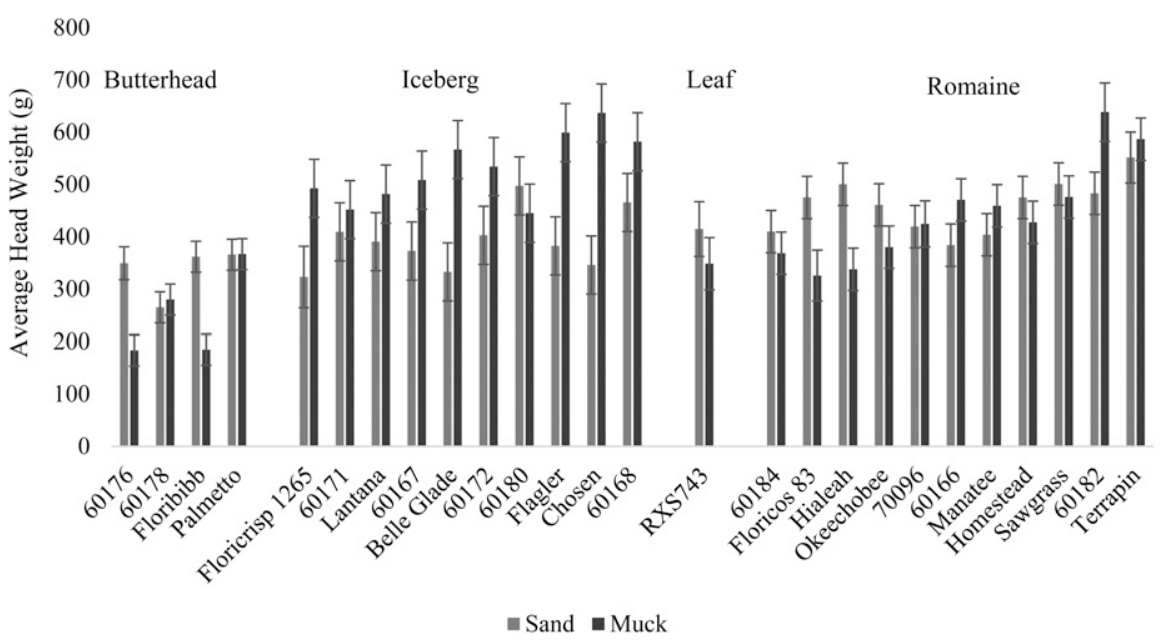

Fig. 4. Least square means (LSM) of head weight (HW) averaged by lettuce cultivars in four experiments conducted between 2017 and 2019 in two soil types, muck and sand near Loxahatchee (sand) and Belle Glade (muck), FL. Least significant difference (LSD; $P=0.05$ ) is presented for soil type $\times$ genotype $(\mathrm{LSD}=126.4)$. via drip tape. The cultivation of lettuce in bare soil confers less efficient control of weeds and fertilizer application. Weeds are among the major challenges for lettuce producers in muck soils due to the limited number of efficient herbicides labeled for lettuce (Odero and Wright, 2013). As a result, the weed interference in lettuce crops can lead to yield losses of $20 \%$ to $48 \%$, which is inherently avoided in sandy soil production with plastic covered beds (Dittmar and Boyd, 2020; Santos et al., 2003).

Lettuce accessions grown in sandy soils had significantly higher incidence of bolting (data not shown), and very low bolting was registered in muck experiments. Romaine lettuces grown in sandy soils had a greater bolting percentage (35\% on average) compared with muck soils $(0 \%)$, with cultivars Terrapin, Okeechobee, Sawgrass, and the breeding line 60182 being the most affected $(85 \%, 56 \%, 53 \%$, and $52 \%$, respectively; data not shown). Similarly, cultivar Floribibb (butterhead), breeding line 60176 (butterhead), RSX743 (leaf), and breeding line 60180 (iceberg) had high bolting percentages when grown in sand $(59 \%, 70 \%, 51 \%$, and $36 \%$, respectively), but low percentage of bolted plants in muck soils $(\leq 10 \%$; data not shown). Furthermore, two butterhead accessions (60178 and Palmetto), five icebergs (60167, 60172, Chosen, Lantana, and Flagler), and two romaine lettuces (60166 and Manatee) did not present bolting across all experiments (data not shown). These results demonstrate the presence of genetic

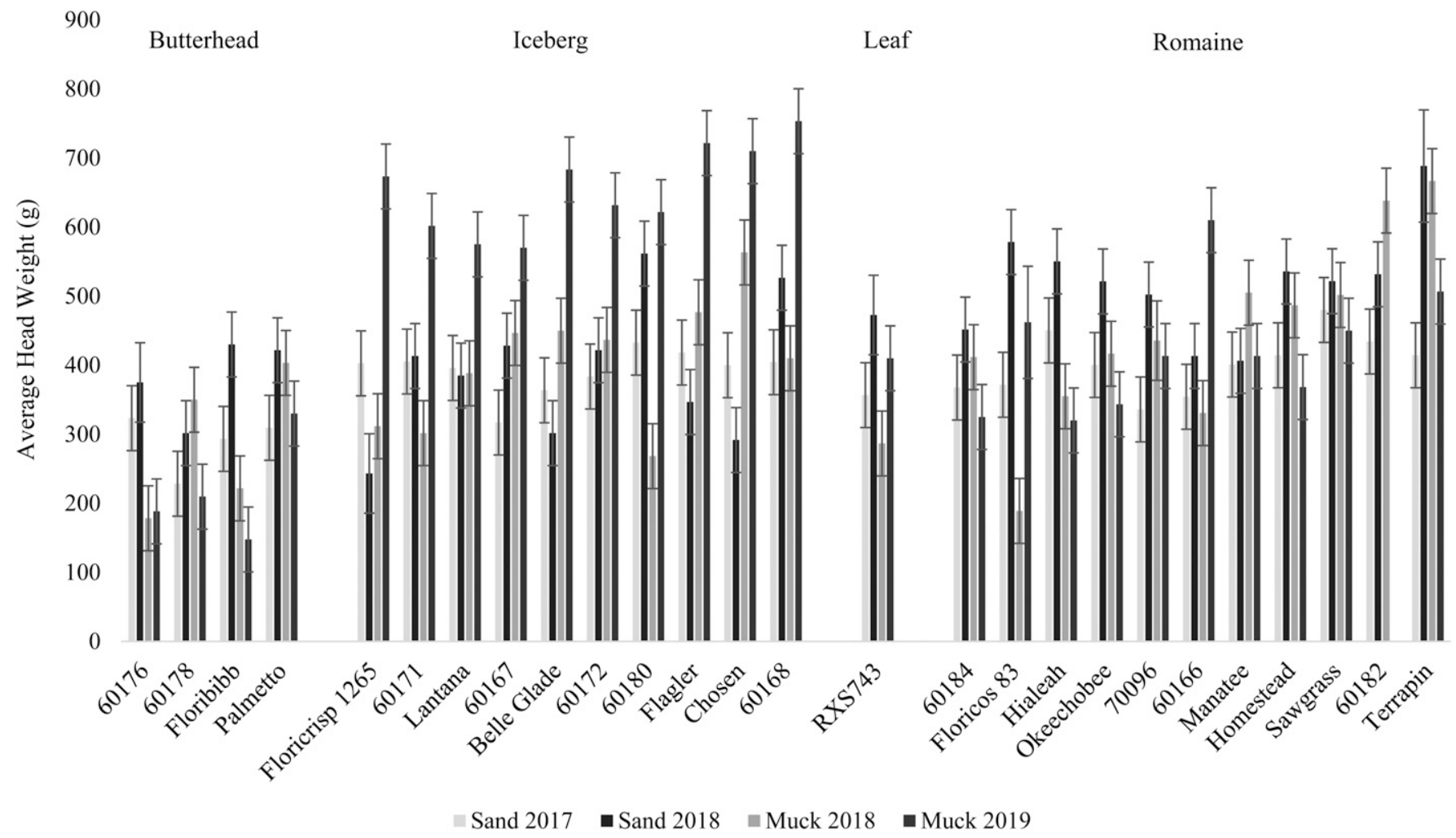

Fig. 5. Least square means (LSM) of head weight (HW) averaged by lettuce cultivars in four experiments conducted between 2017 and 2019 in two soil types, muck and sand near Loxahatchee (sand) and Belle Glade (muck), FL. Least significant difference (LSD; $P=0.05$ ) is presented for cultivar/line $\times$ experiment $(\mathrm{LSD}=133.6)$. 
Table 5. Least square means (LSM) of percentage of marketable heads and tipburn in 25 lettuce cultivars and breeding lines planted in two experiments each on muck and sandy soils near Loxahatchee (sand) and Belle Glade (muck), FL.

\begin{tabular}{|c|c|c|c|c|c|c|c|c|c|c|}
\hline \multirow[b]{3}{*}{ Cultivar/line } & \multicolumn{5}{|c|}{ Marketability (\%) } & \multicolumn{5}{|c|}{ Tipburn (\%) } \\
\hline & \multicolumn{2}{|c|}{ Sand } & \multicolumn{2}{|c|}{ Muck } & \multirow[b]{2}{*}{ Avg } & \multicolumn{2}{|c|}{ Sand } & \multicolumn{2}{|c|}{ Muck } & \multirow[b]{2}{*}{ Avg } \\
\hline & 2017 & 2018 & 2018 & $2019^{z}$ & & 2017 & 2018 & 2018 & 2019 & \\
\hline \multicolumn{11}{|l|}{ Butterhead } \\
\hline 60176 & 0 & 64 & 37 & - & 34 & 45 & 4 & 0 & 0 & 12 \\
\hline 60178 & 0 & 42 & 59 & - & 34 & 62 & 25 & 0 & 0 & 22 \\
\hline Floribibb & 100 & 78 & 59 & - & 79 & 0 & 0 & 0 & 0 & 0 \\
\hline Palmetto & 100 & 82 & 79 & - & 87 & 48 & 0 & 0 & 0 & 12 \\
\hline $\operatorname{LSD}(G)^{y}$ & 24.6 & & & & & 16.9 & & & & \\
\hline $\operatorname{LSD}(S)^{x}$ & 29.2 & & & & & 13.0 & & & & \\
\hline $\operatorname{LSD}(E)^{\mathrm{w}}$ & 33.8 & & & & & 15.4 & & & & \\
\hline $\operatorname{LSD}(\mathrm{G} \times \mathrm{S})^{\mathrm{v}}$ & 37.1 & & & & & 23.9 & & & & \\
\hline $\operatorname{LSD}(\mathrm{G} \times \mathrm{E})^{\mathrm{u}}$ & 32.9 & & & & & 27.5 & & & & \\
\hline \multicolumn{11}{|l|}{ Iceberg } \\
\hline 60167 & 73 & 89 & 30 & - & 64 & 2 & 7 & 0 & 0 & 2 \\
\hline 60168 & 30 & 91 & 17 & - & 46 & 0 & 11 & 0 & 0 & 3 \\
\hline 60171 & 82 & 96 & 10 & - & 63 & 0 & 6 & 0 & 2 & 2 \\
\hline 60172 & 50 & 86 & 26 & - & 54 & 2 & 0 & 0 & 0 & 0 \\
\hline 60180 & 48 & 0 & 2 & - & 17 & 37 & 0 & 0 & 16 & 13 \\
\hline Belle Glade & 72 & 80 & 20 & - & 57 & 0 & 3 & 0 & 0 & 1 \\
\hline Chosen & 83 & 67 & 64 & - & 71 & 3 & 2 & 0 & 0 & 1 \\
\hline Flagler & 83 & 97 & 55 & - & 78 & 0 & 0 & 0 & 0 & 0 \\
\hline Floricrisp 1265 & 90 & 76 & 25 & - & 64 & 3 & 0 & 0 & 0 & 1 \\
\hline Lantana & 88 & 92 & 35 & - & 72 & 2 & 0 & 0 & 0 & 0 \\
\hline $\operatorname{LSD}(\mathrm{G})$ & 20.7 & & & & & 6.0 & & & & \\
\hline $\operatorname{LSD}(\mathrm{S})$ & 11.7 & & & & & 3.0 & & & & \\
\hline LSD (E) & 12.6 & & & & & 3.5 & & & & \\
\hline $\mathrm{LSD}(\mathrm{G} \times \mathrm{S})$ & 29.2 & & & & & 8.5 & & & & \\
\hline LSD $(\mathrm{G} \times \mathrm{E})$ & 28.7 & & & & & 9.6 & & & & \\
\hline \multicolumn{11}{|l|}{ Leaf } \\
\hline RSX743 & 100 & 100 & 48 & - & 83 & 0 & 2 & 0 & 0 & 1 \\
\hline $\operatorname{LSD}(\mathrm{S})$ & 20.6 & & & & & 2.2 & & & & \\
\hline LSD (E) & 25.4 & & & & & 3.3 & & & & \\
\hline \multicolumn{11}{|l|}{ Romaine } \\
\hline 60166 & 60 & 87 & 13 & - & 53 & 3 & 9 & 0 & 0 & 3 \\
\hline 60182 & 65 & 76 & 57 & - & 66 & 0 & 2 & 0 & - & 1 \\
\hline 60184 & 30 & 98 & 44 & - & 57 & 0 & 7 & 0 & 0 & 2 \\
\hline 70096 & 63 & 100 & 66 & - & 76 & 12 & 4 & 0 & 0 & 4 \\
\hline Floricos 83 & 60 & 88 & 17 & - & 55 & 0 & 0 & 0 & 0 & 0 \\
\hline Hialeah & 88 & 96 & 26 & - & 70 & 10 & 4 & 0 & 0 & 4 \\
\hline Homestead & 70 & 94 & 38 & - & 67 & 0 & 10 & 0 & 0 & 3 \\
\hline Manatee & 82 & 84 & 58 & - & 75 & 10 & 3 & 0 & 0 & 3 \\
\hline Okeechobee & 95 & 96 & 44 & - & 78 & 0 & 2 & 0 & 0 & 1 \\
\hline Sawgrass & 68 & 98 & 42 & - & 69 & 2 & 4 & 0 & 0 & 2 \\
\hline Terrapin & 53 & 100 & 67 & - & 73 & 5 & 0 & 0 & 0 & 1 \\
\hline $\operatorname{LSD}(\mathrm{G})$ & 18.1 & & & & & 4.8 & & & & \\
\hline LSD (S) & 22.0 & & & & & 2.3 & & & & \\
\hline LSD (E) & 13.1 & & & & & 3.4 & & & & \\
\hline $\mathrm{LSD}(\mathrm{G} \times \mathrm{S})$ & 28.3 & & & & & 6.8 & & & & \\
\hline $\mathrm{LSD}(\mathrm{G} \times \mathrm{E})$ & 27.8 & & & & & 9.8 & & & & \\
\hline Environment & 67 & 83 & 39 & & & 10 & 4 & 0 & 1 & \\
\hline
\end{tabular}

${ }^{\mathrm{z}}$ Data for marketability in this experiment was lost.

${ }^{\mathrm{y}}$ Least significant difference (LSD; $\left.P=0.05\right)$ for genotype $(\mathrm{G})$.

${ }^{\mathrm{x}} \operatorname{LSD}(P=0.05)$ for soils $(\mathrm{S})$.

${ }^{\mathrm{w}} \operatorname{LSD}(P=0.05)$ for environment $(\mathrm{E})$.

${ }^{\mathrm{v}} \mathrm{LSD}(P=0.05)$ for $\mathrm{G} \times \mathrm{S}$.

${ }^{\mathrm{u}} \mathrm{LSD}(P=0.05)$ for $\mathrm{G} \times \mathrm{E}$.

variability for bolting among the lettuce germplasm tested in sand vs. muck, which may be in addition to temperature and photoperiod (environment) regardless of soil type (Hao et al., 2018; Holmes et al., 2019; Jenni and Yan, 2009). Furthermore, the higher incidence of bolting in sandy soils could be partially explained by the longer number of days from sowing to harvest in Expts. 1 and 2 compared with those conducted in muck soils (Expts. 3 and 4) (Table 2).

Tipburn was mostly found in sandy soil experiments rather than in muck soil experiments $(P=0.0008)$, especially in the 2017 experiment (Table 5), which was planted in December when temperatures were more suitable for lettuce production. Differences were also observed at the germplasm level $(P<0.0001$; Table 3$)$, which indicate genetic variability in the germplasm tested as previously reported (Jenni and Hayes, 2010; Ryder and Waycott, 1998). Although many values were minimal in this research, butterhead (60176 and 60178) and iceberg breeding lines (60180) were the germplasm with higher percentage of tipburn (Table 5). One iceberg breeding line (60172); two formerly released cultivars (Floribibb and Floricos 83) of butterhead and romaine, respectively; and two iceberg commercial cultivars (Flagler and Lantana) produced no tipburn across all experiments (Table 5). The genetic variation identified for tipburn in lettuce is typically more distinct when planted in extremely warm environments (Lafta et al., 2017), but these results also demonstrate that $\mathrm{G} \times \mathrm{E}$ interaction for tipburn may exist for different soil types.

Genotype $\times$ environment interaction for $H W$ in lettuce. This research was conducted in muck and sandy soils by planting lettuce breeding lines and cultivars that have been 
exclusively bred and adapted to muck soils in the EAA of South Florida. We discovered that HW, marketability, and tipburn presented a significant genotype $\times$ soil $(\mathrm{G} \times \mathrm{S})$ interaction $(P<0.0001)$ in the ANOVA (Table 3 ). A significant lettuce type $\times$ soil interaction was also identified in iceberg $(P=$ $0.0040)$, butterhead $(P<0.0001)$, and romaine $(P=0.0003)$ lettuces for HW, wheresas only the interaction of romaine $\times$ soil was significant $(P=0.0099)$ for marketability and

no interaction of each of the studied types $\times$ soil was significant $(P>0.05)$ for tipburn, despite the overall significant interaction among all lettuce types (Table 3). If an interaction plays a role in $\mathrm{HW}$, this might be a crossover type interaction because correlations were weak and nonsignificant $(P>$ $0.05)$ among experiments (Expts. 1-4), except for experiments Expts. 1 and $2(r=0.26$; $P=0.0292)$ and Expts. 1 and $4(r=0.29 ; P=$ 0.0128 ) (Table 6). This lack of positive and

Table 6. Correlations ( $P$ values) for head weight among four experiments conducted in sandy and muck soils.

\begin{tabular}{lcccr}
\hline Expt. & $\begin{array}{c}\text { Expt. 1 } \\
\text { (sand 2017) }\end{array}$ & $\begin{array}{c}\text { Expt. 2 } \\
\text { (sand 2018) }\end{array}$ & $\begin{array}{c}\text { Expt. 3 } \\
\text { (muck 2018) }\end{array}$ & $\begin{array}{r}\text { Expt. 4 } \\
\text { (muck 2019) }\end{array}$ \\
\hline Expt. 1 (sand 2017) & - & $0.26(0.0292)$ & $0.21(0.0752)$ & $0.29(0.0128)$ \\
Expt. 2 (sand 2018) & & - & $-0.13(0.2582)$ & $-0.13(0.3030)$ \\
Expt. 3 (muck 2018) & & & - & $0.23(0.0562)$ \\
Expt. 4 (muck 2019) & & & & - \\
\hline
\end{tabular}

strong correlations between muck and sandy soils also indicate a significant $\mathrm{G} \times \mathrm{E}$ interaction for HW, and therefore, breeding for lettuce cultivars adapted to sandy soils should be conducted in sandy soil environments, especially if lettuce is planted in warmer conditions (Jenni and Hayes, 2010; Jenni and Yan, 2009).

We used a GGE Biplot to visualize megaenvironments depending on lettuce performance across environments. A mega-environment is defined as the environment or environments in which germplasms perform statistically the same and the interaction with the environment is minimum. In the GGE Biplot, megaenvironments are visualized with the whichwon-where method graphed in a polygon to identify the germplasm(s) suitable for a specific mega-environment (one environment or the combination of several), which informs breeders of the location(s) on which selections should be carried out. As a result, we

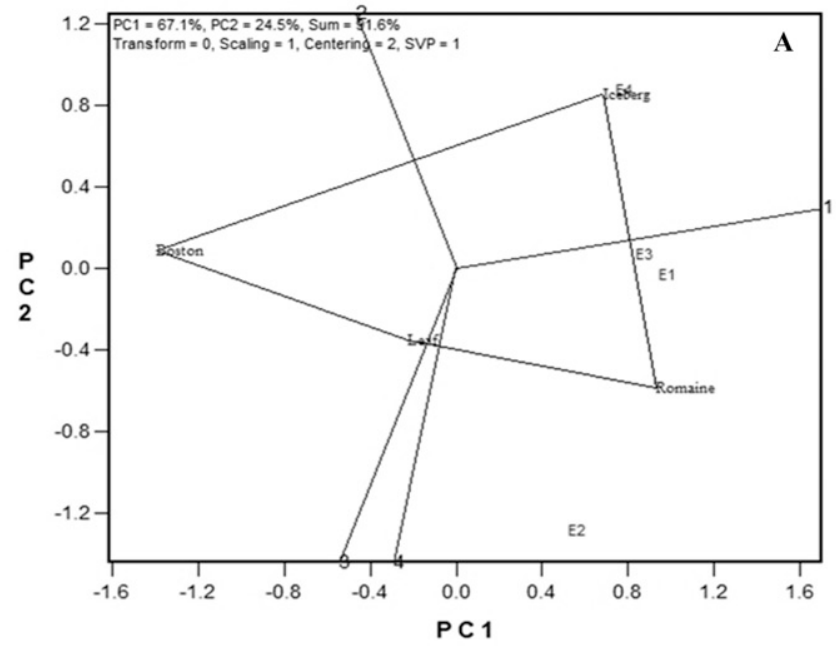

Which wins where or which is best for what

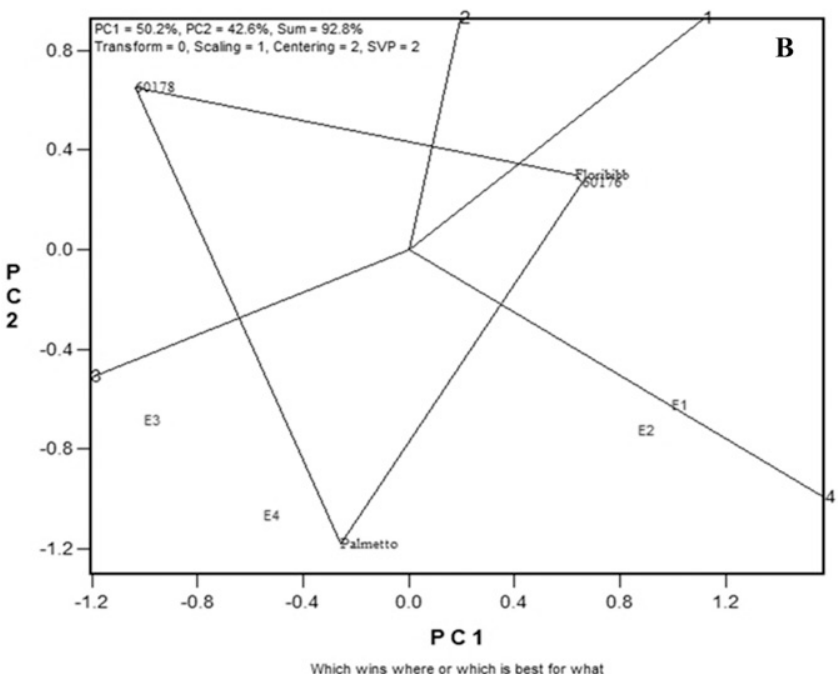

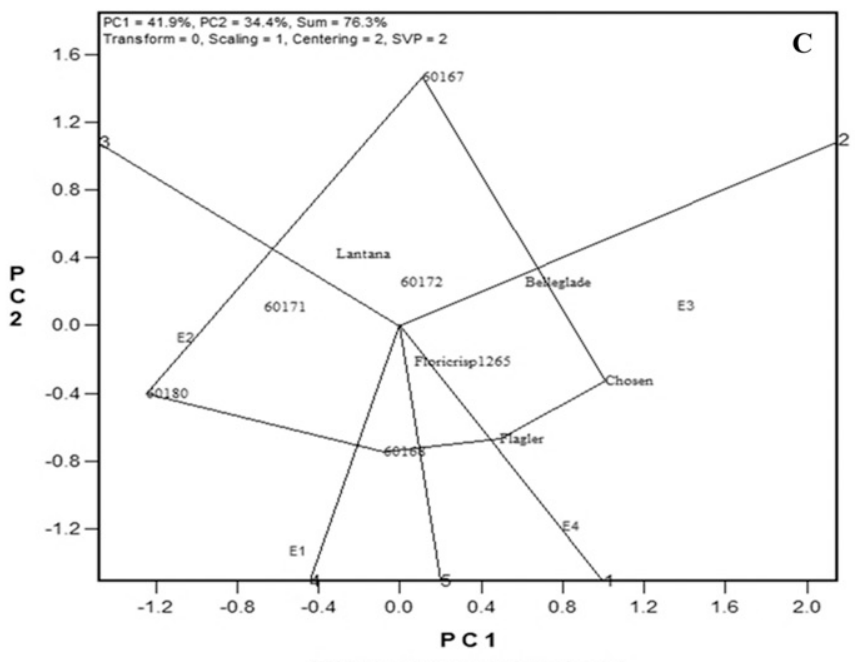

Which wins where or which is best for what

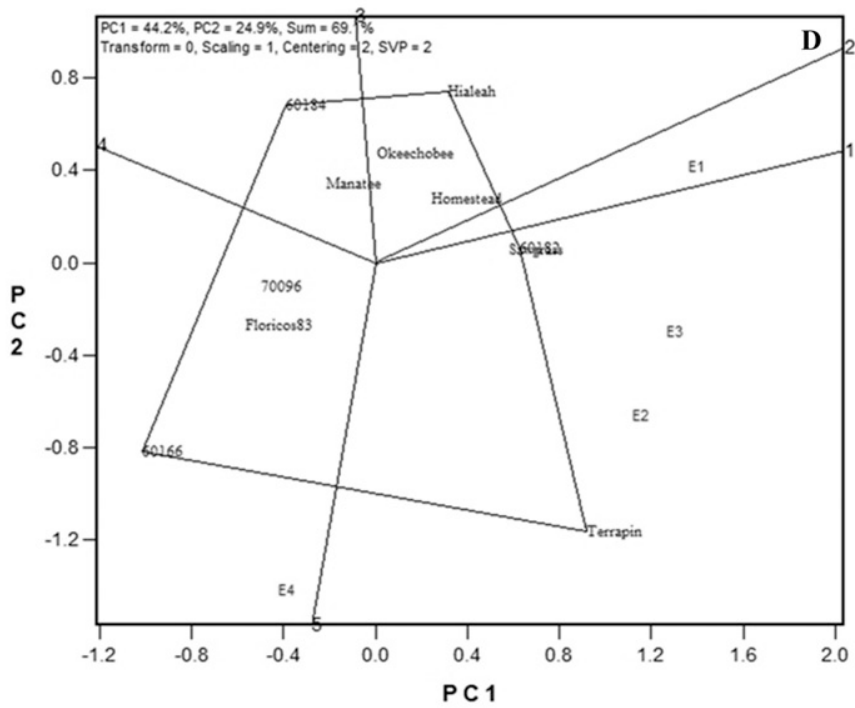

Which wins where or which is best for what

Fig. 6. Which-won-where of the GGE Biplot for types of lettuce (A). Biplots are presented for only butterhead (B), iceberg (C), and romaine (D) lettuce breeding lines and cultivars planted in Expt. 1 (E1) in sandy soils in 2017, Expt. 2 (E2) in sandy soils in 2018, Expt. 3 (E3) in muck soils in 2018, and Expt. 4 (E4) in muck soils in 2019 . 
displayed the data of HW in a GGE biplot that helps to understand the $\mathrm{G} \times \mathrm{S}$ interaction in a graphic fashion (Yan, 2001). In a Biplot graphed by type of lettuce regardless of individual accessions, romaine lettuce had better and more stable HW in three of the environments tested Expts. 1, 2, and 3 (Sandy 2018, Sandy 2018, and Muck 2019) that were grouped as mega-environment 1, whereas iceberg lettuce was better in E4 (Muck 2019) in megaenvironment 2 (Fig. 6A).

Biplots for HW are also presented for genotypes grouped in three lettuce types, butterhead, iceberg, and romaine lettuces, in Fig. 6B-D, respectively. The GGE Biplot divided the 4 experiments in two megaenvironments: Expt. 1 (Sandy 2017) as one mega-environment and the other three Expts. 2, 3, and 4 (Sandy 2018, Muck 2018, and Muck 2019) in a second mega-environment for HW in butterhead lettuce. Interestingly, one breeding line (60176) and one obsolete cultivar (Floribibb) are positioned as the "winners" in mega-environment Expt. 1. Cultivar Palmetto is the winner in the second mega-environment and does well in three of the four experiments in this research, which is not surprising as the cultivar has been extensively used by growers in south Florida (Fig. 6B). In this research, a small group of butterhead lettuces were tested and most likely using a higher group of lines and cultivars may allow the identification of better suited butterhead lettuce cultivars for sandy soils.

In iceberg lettuce, two mega-environments were identified for all lettuce cultivars and breeding lines planted in four experiments. In mega-environment 1, Expts. 1 and 2 (Sandy 2017 and 2018) were grouped together on the unfavorable side (negative $\mathrm{x}$ and $\mathrm{y}$ axes) of the polygon. In mega-environment 2, Expts. 3 and 4 (Muck 2018 and 2019) were grouped together in a fair side of the polygon. However, only Expt. 3 falls into the productive side of the polygon (positive $\mathrm{x}$ and $\mathrm{y}$ axes), indicating the value of this group of icebergs for muck soils but not for sandy soils, in agreement with results previously described in this study (Fig. 6C). In mega-environment 2, 'Chosen' was the winner, a lettuce cultivar preferentially planted in the EAA during the early lettuce season (Sandoya and $\mathrm{Lu}, 2020$ ).

In romaine lettuce, three mega-environments were identified as Expt. 1 (Sand 2017), Expts. 2 and 3 (Sand 2018 and Muck 2018), and Expt. 4 (Muck 2019). Interestingly, no romaine line or cultivar is graphed as the winner in Expt. 1. In the second mega-environment, cultivars Terrapin and Sawgrass, and breeding line 60182 were the winners, even though part of the mega-environment was graphed into the positive $\mathrm{x}$ and the negative $\mathrm{y}$ of the cartesian plane (Fig. 6D). The GGE biplot proved that romaine lettuce has good yield potential in sandy soils, as previously described and breeding lettuce cultivars adapted to sandy soils, especially romaine, should be conducted in sandy soil environments.

Adaptability of romaine accessions to early season planting in sandy soils. Three romaine breeding lines and one obsolete cultivar were planted near the northern Florida town of Hastings to test the performance of romaine lettuce planted in sandy soil, $\approx 1$ month before the current lettuce season in South Florida. Transplanting seedlings were initially grown in two locations, one in Blairsville, GA, and one in Sun City, FL. During the 3 weeks before transplanting, the Georgia location had an average temperature of 24 and $23{ }^{\circ} \mathrm{C}$, respectively, in the first planting on 15 Aug. 2019 and in the second planting on 26 Aug. 2019, whereas the first and second plantings in Florida both had an average temperature of $27^{\circ} \mathrm{C}$. Although the maximum temperatures in both locations during those 3 weeks did not vary appreciably (between 30 and $33{ }^{\circ} \mathrm{C}$ ), the variation between minimum temperatures was more pronounced (between 15 to $23{ }^{\circ} \mathrm{C}$ ) (Table 4). On average, temperatures ranged from 24 to $26{ }^{\circ} \mathrm{C}$ while romaine lettuce was in the ground for the first transplanted experiment (Expt. 5) and ranged from 17 to $24{ }^{\circ} \mathrm{C}$ while romaine lettuce was in the ground for the second transplanted experiment (Expt. 6) in northern Florida (Table 4). We found significant differences between the two planting times (15 Aug. 2019 and 26 Aug. 2019; $P=$ $0.0025)$, among romaine accessions $(P=$ $0.0019)$ and between locations where seedlings were initiated (Florida and Georgia; $P<$ 0.0001 ) based on final HW measurements. There were also several significant interactions in the ANOVA $(P<0.05)$ such as genotype $\times$ planting and location $\times$ planting (Table 7).

Overall, romaine lettuce had a higher HW when transplants were initiated at the Georgia location in both experiments (Fig. 7), probably due to lower night temperatures (Table 4). Most lettuce performs best in cool weather where day temperatures range between 18 and $25^{\circ} \mathrm{C}$ and night temperatures 10 and $15{ }^{\circ} \mathrm{C}$, whereas higher temperatures negatively affect lettuce yields through reduced plant initiation and early flowering time (Cantliffe et al., 1981; Lafta and Mou, 2013). In this study, the minimum temperature in Aug. 2019 was $17{ }^{\circ} \mathrm{C}$ in Georgia and $23{ }^{\circ} \mathrm{C}$ in Florida (Table 4). As a result of this $6{ }^{\circ} \mathrm{C}$ difference, it is likely that the above

Table 7. Analysis of variance of head weight and bolting of four romaine accessions planted in two experiments in sandy soils near Hastings, FL. Seedlings for these experiments were started at two geographic locations in Georgia (Blairsville) and Florida (Sun City).

\begin{tabular}{|c|c|c|c|c|c|c|}
\hline \multirow[b]{2}{*}{ Source of variation } & \multirow[b]{2}{*}{$\mathrm{df}_{\text {num }}{ }^{\mathrm{z}}$} & \multirow[b]{2}{*}{$\mathrm{df}_{\mathrm{den}}^{\mathrm{z}}$} & \multicolumn{2}{|c|}{ Head weight } & \multicolumn{2}{|c|}{ Bolting } \\
\hline & & & F value & $P$ value & F value & $P$ value \\
\hline Genotype & 3 & 28 & 6.39 & 0.0019 & 5.08 & 0.0062 \\
\hline Nursery & 1 & 28 & 29.37 & $<0.0001$ & 44.83 & $<0.0001$ \\
\hline Genotype $\times$ nursery & 3 & 28 & 0.50 & 0.6858 & 1.18 & 0.3364 \\
\hline Experiment & 1 & 4 & 45.53 & 0.0025 & 60.50 & 0.0015 \\
\hline Genotype $\times$ experiment & 3 & 28 & 4.26 & 0.0135 & 2.62 & 0.0701 \\
\hline Nursery $\times$ experiment & 1 & 28 & 5.72 & 0.0237 & 19.36 & 0.0001 \\
\hline Genotype $\times$ nursery $\times$ experiment & 3 & 28 & 1.07 & 0.3757 & 0.65 & 0.5899 \\
\hline
\end{tabular}

${ }^{\mathrm{z}} \mathrm{df}_{\text {num }}$ is the degree of freedom of numerator, and $\mathrm{df}_{\mathrm{den}}$ is the degree of freedom of denominator.

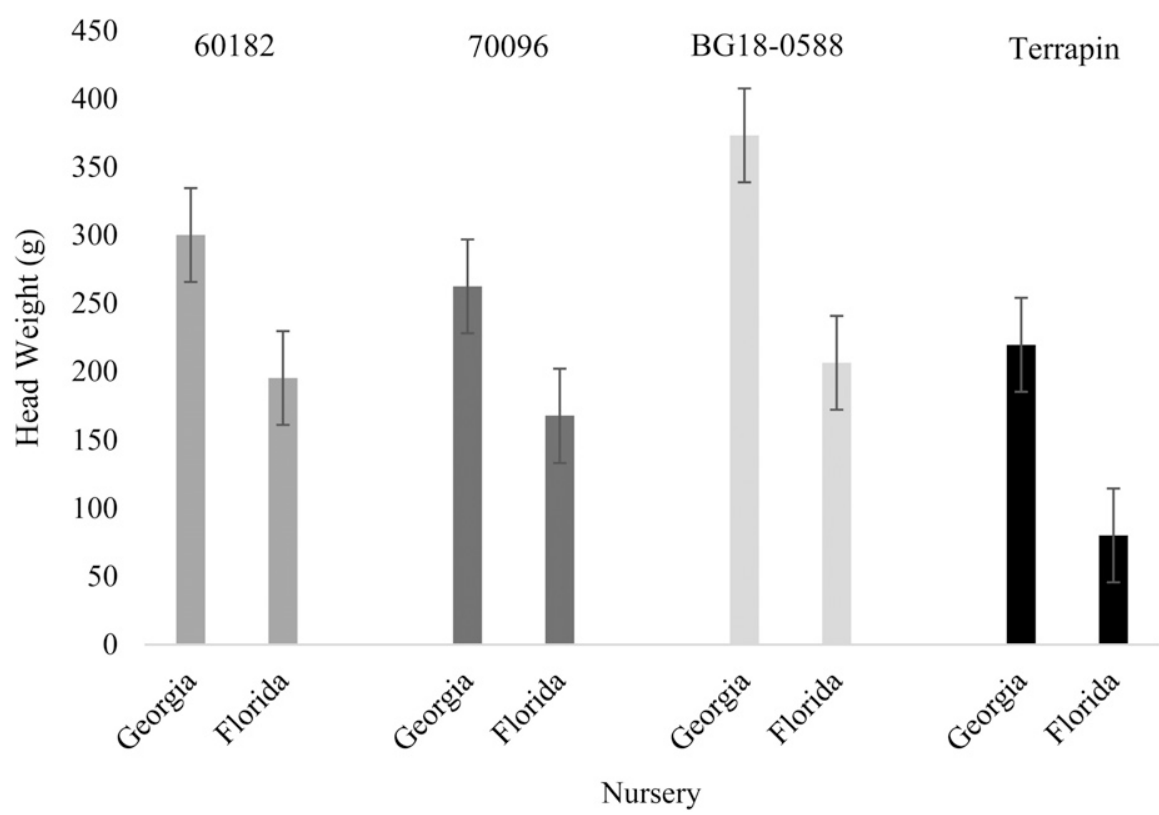

Fig. 7. Least square means (LSM) of head weight of three romaine breeding lines and one cultivar planted in nurseries in Georgia and Florida and transplanted in Hastings, FL. Error bars correspond with the SE of the LSM. Least significance difference (LSD; $P=0.05)$ is presented for cultivar/line $(\mathrm{LSD}=67.6)$, nursery $(\mathrm{LSD}=47.8)$, and cultivar/line $\times$ nursery $(\mathrm{LSD}=95.6)$ interaction. 
optimal minimum temperatures in Florida caused the lettuce to bolt faster and reduce time spent in vegetative growth (Table 8). These results suggest that the Georgia location is an ideal nursery for early planting when considering planting romaine lettuce in sandy soils, as supported by the higher bolting incidence among seedlings started in Florida (Table 8).

Considering differences in HW among genotypes across the two planting dates, the romaine breeding line BG18-0588 had the highest average HW followed by lines 60182 , 70096, and cultivar Terrapin for both nurser- ies (Fig. 7). Moreover, the yield of BG180588 remained consistent in both planting dates when transplants were obtained from Georgia, while the transplants from Florida performed significantly worse. The HW of 60182, 70096, and Terrapin were more negatively impacted by the first planting date regardless of transplant location (Fig. 8). These three genotypes did yield higher in the second experiment, especially among the Georgia transplants, suggesting that more genotypes may be suitable for a more modest, but still early, planting.

Table 8. Least square means of percentage of bolted plants in three romaine breeding lines and one cultivar planted in nurseries in Georgia and Florida (15 Aug. 2019 and 26 Aug. 2019) and transplanted in Hastings, FL.

\begin{tabular}{|c|c|c|c|c|}
\hline \multirow[b]{2}{*}{ Cultivar/Line } & \multicolumn{2}{|c|}{ Planting 15 Aug. } & \multicolumn{2}{|c|}{ Planting 26 Aug. } \\
\hline & Georgia & Florida & Georgia & Florida \\
\hline 60182 & 35 & 97 & 0 & 0 \\
\hline 70096 & 48 & 100 & 0 & 8 \\
\hline BG18-0588 & 7 & 68 & 0 & 0 \\
\hline Terrapin & 33 & 100 & 0 & 50 \\
\hline Average & 31 & 91 & 0 & 14 \\
\hline $\operatorname{LSD}(G)^{\mathrm{z}}$ & 15.7 & & & \\
\hline $\operatorname{LSD}(\mathrm{P})^{\mathrm{y}}$ & 18.8 & & & \\
\hline $\operatorname{LSD}(N)^{x}$ & 11.1 & & & \\
\hline $\operatorname{LSD}(\mathrm{G} \times \mathrm{P})^{\mathrm{w}}$ & 23.1 & & & \\
\hline $\operatorname{LSD}(\mathrm{G} \times \mathrm{N})^{\mathrm{v}}$ & 22.3 & & & \\
\hline $\operatorname{LSD}(\mathrm{N} \times \mathrm{P})^{\mathrm{u}}$ & 17.1 & & & \\
\hline $\operatorname{LSD}(\mathrm{G} \times \mathrm{N} \times \mathrm{P})^{\mathrm{t}}$ & 32.1 & & & \\
\hline
\end{tabular}

${ }^{\mathrm{z}}$ Least significant difference $(\mathrm{LSD} ; P=0.05)$ for genotype $(\mathrm{G})$.

${ }^{\mathrm{y}} \operatorname{LSD}(P=0.05)$ for planting $(\mathrm{P})$.

${ }^{\mathrm{x}} \operatorname{LSD}(P=0.05)$ for nursery $(\mathrm{N})$.

${ }^{\mathrm{w}} \mathrm{LSD}(P=0.05)$ for genotype $\times$ planting $(\mathrm{G} \times \mathrm{P})$.

${ }^{\mathrm{v}} \mathrm{LSD}(P=0.05)$ for genotype $\times$ nursery $(\mathrm{G} \times \mathrm{N})$.

${ }^{\mathrm{u}} \mathrm{LSD}(P=0.05)$ for nursery $\times$ planting $(\mathrm{N} \times \mathrm{P})$.

${ }^{\mathrm{t}} \mathrm{LSD}(P=0.05)$ for genotype $\times$ nursery $\times$ planting $(\mathrm{G} \times \mathrm{N} \times \mathrm{P})$.

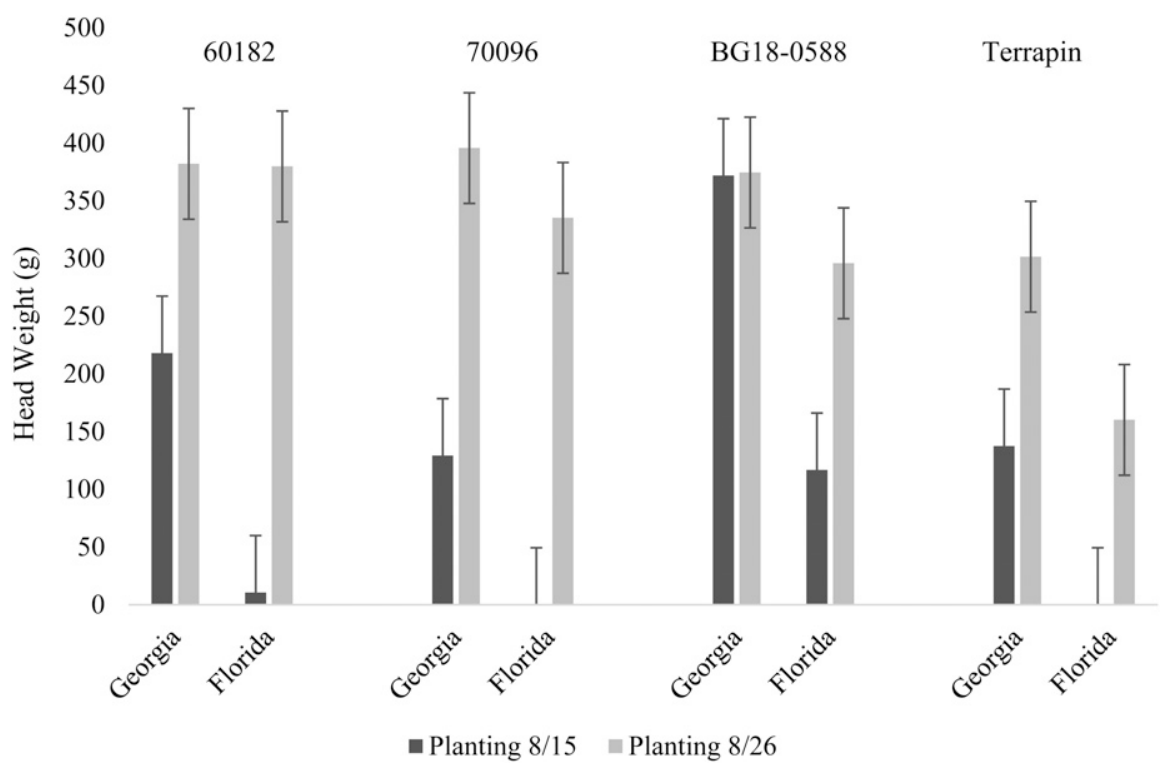

Fig. 8. Least square means (LSM) of head weight of three romaine breeding lines and one cultivar planted in nurseries in Georgia and Florida (15 Aug. 2019 and 16 Aug. 2019) and transplanted in Hastings, FL. Error bars correspond with the standard error of the LSM. Least significance difference (LSD; $P=$ $0.05)$ is presented for cultivar/line $(\mathrm{LSD}=67.6)$, nursery $(\mathrm{LSD}=47.8)$, planting date $(\mathrm{LSD}=84.4)$, and the interactions of cultivar/line $\times$ nursery $(\mathrm{LSD}=95.6)$, cultivar/line $\times$ planting date $(\mathrm{LSD}=100.2)$, nursery $\times$ planting date $(\mathrm{LSD}=74.9)$, and cultivar/line $\times$ planting date $\times$ nursery $(\mathrm{LSD}=138.3)$.
During the early season trials, bolting was highest in the first experiment when transplants originated from Florida, with an average bolting of $91 \%$. Such a high percentage even prevented measuring HW data for '70096' and 'Terrapin'. On the other hand, Georgia's transplants in the first experiment registered an average of $31 \%$ of bolted plants, indicating that attempting to transplant at such an early date may not be possible for many genotypes. The second planting registered less bolting from Florida transplants (14\%), which only occurred for line 70096 $(8 \%)$ and cultivar Terrapin $(50 \%)$, and no Georgia transplants bolted among any of the tested romaine breeding lines and cultivar (Table 8). This demonstrates that Georgia has greater potential as an early transplant nursery; however, specific bolting data should be generated for each cultivar to determine the best nursery location for transplants, especially when pushing lettuce planting to its earliest possible dates in Florida.

These observations indicate that certain genotypes, such as BG18-0588, might be less affected by warmer temperatures during very early plantings and further investigation is warranted to identify superior lines for early production in Florida's sandy soils. Results from breeding lines 60182 and 70096 show that although some lines may not be recommended for very early planting, even when using a cooler environment for seedling initiation, they are still a viable option for planting during slightly later dates that are still relatively early compared with the EAA season. This is evident by the fact that in E6, breeding line 60182 showed an almost identical HW between the two nursery locations (Fig. 8). Although HW was higher for 70096 and BG18-0588 when transplants were initiated in Georgia, these differences were not significant compared with the HW obtained using transplants from Florida (Fig. 8). Overall, this data warrants the screening of more romaine cultivars for adaptability to transplant nursery locations, acceptable HW, low tipburn, and little to no bolting when planted at moderately early dates in North Florida.

Comparing results across all four sandy experiments in Loxahatchee and Hastings, FL. Three romaine accessions (60182, 70096, and 'Terrapin') tested in both sandy soil locations presented a higher average yield when grown in Loxahatchee compared with Hastings, FL (Figs. 5-8), which may be explained by differences in fertilization and crop management strategies applied in each location. In addition, the Hastings experiments were conducted about one month before the beginning of South Florida's lettuce season, and therefore, warmer temperatures may have affected the yield and quality of lettuce plants (Lafta et al., 2017). Another contributing factor is that these three accessions were bred for cultivation in South Florida and may be adapted to shorter photoperiods. Future experiments could investigate whether improving fertilizer regiments could offset these latter two environmental conditions, or whether genotypes could be 
identified that are less detrimentally impacted by these conditions.

\section{Conclusions}

In this research, genetic differences for HW and other heat-related stresses such as bolting and tipburn were observed among the breeding lines and cultivars tested in muck and sandy soils and these differences were most notable in romaine and butterhead lettuce; in addition, iceberg lettuce was not suitable for sandy soils. Overall, HW was better in sandy soil experiments in romaine cultivar Terrapin and breeding line 70096, which had no interactions between muck and sandy soils, whereas breeding line 60182 had an equivalent HW in both soils. The significant $\mathrm{G} \times \mathrm{E}$ interaction indicated that romaine lettuce is more suited for sandy soils based on HW, and therefore, breeding romaine lettuce for sandy soils should be conducted in sandy environments, as seen in the GGE Biplot. If selection is targeted, evaluations for HW and related traits should be conducted in several trials and locations as $\mathrm{G} \times \mathrm{E}$ seems to be a crossover type; further testing in several sand locations and the increase of accessions could help to understand the $\mathrm{G} \times \mathrm{E}$ interaction.

This research demonstrates that planting romaine lettuce in sandy soils could be beneficial to Florida growers. This lettuce type has become popular among leafy vegetable consumers in the United States. Romaine lettuce represents $35 \%$ of the total area planted in the country (USDA NASS, 2019). This trend in increased romaine preference has been occurring ever since this type of lettuce became one of the top 10 most consumed vegetables in the United States (Hayes, 2018), and producers could improve profits by meeting future demand increases through expanding their production into marginalized sandy soils. The crop could also have the potential to become a new, earlier planted crop in the sandy soils of northern Florida. If early planting becomes a reality in Florida, these results suggest that lettuce producers will need cooler nursery environments to produce seedlings, such as the Georgia location used in this study, with minimum temperatures below $18{ }^{\circ} \mathrm{C}$. Using nurseries with higher temperatures during both early and late seasons, such as the nursery in Sun City, FL, would be more restricted to particularly heat-tolerant cultivars, such as the only heat-tolerant lettuce found in this research, BG18-0588.

Additionally, detrimental warm August temperatures could be avoided in northern Florida by adjusting the planting window by as little as $10 \mathrm{~d}$, depending on yearly conditions, which still places a significant advantage over the necessarily later planting dates required in the warmer EAA. As a result, these early plantings would not interfere with the timing of the current Florida lettuce industry in the EAA because the asynchronous harvest dates would not compete for the same markets simultaneously. Lastly, additional beneficial practices, such as bed mulching, fertigation, and transplanting required for producing lettuce in sand, may increase lettuce profitability through improved weed control and nutrient timing. Therefore, the results found in this study justify further economic analysis to investigate the feasibility of expanding Florida's current lettuce industry into sandy soils.

\section{Literature Cited}

Alkhader, A.M.F., M.M. Qaryouti, and T.Y.M Okasheh. 2019. Effect of nitrogen on yield, quality, and irrigation water use efficiency of drip fertigated grafted watermelon (Citrullus lanatus) grown on a calcareous soil. J. Plant Nutr. 42(7):737-748, doi: 10.1080/01904167. 2019.1568464

Barta, D.J. and T.W. Tibbits. 2000. Calcium localization and tipburn development in lettuce leaves during early enlargement. J. Amer. Soc. Hort. Sci. 125(3):294-298, doi: 10.21273/ JASHS.125.3.294.

Bhadha, J.H., A.L. Wright, and G.H. Snyder. 2020. Everglades Agricultural Area soil subsidence and sustainability (SL311). EDIS 2020(2):1-4. https://journals.flvc.org/edis/article/view/115416/ 119313.

Birthisel, S.K., G.A. Smith, G.M. Mallory, J. Hao, and E.R. Gallandt. 2019. Effects of field and greenhouse solarization on soil microbiota and weed seeds in the northeast USA. Org. Farming 5(1):66-78, doi: 10.12924/of2019.05010066.

Cantliffe, D.J., G.J. Hochmuth, Z. Karchi, and I. Secker. 1997. Nitrogen fertility requirement for iceberg lettuce grown on sandland with plastic mulch and drip irrigation. Proc. Annu. Meet. Fla. State Hort. Soc. 110:306-309.

Cantliffe, D.J. and Z. Karchi. 1992. Performance of crisphead lettuce cultivars on polythylenemulched, drip-irrigated sandy soils in Florida. Proc. Annu. Meet. Fla. State Hort. Soc. 105: 340-342.

Cantliffe, D.J., K.D. Shuler, and A.C. Guedes. 1981. Overcoming seed thermodormancy in a heat-sensitive romaine lettuce by seed priming. HortScience 16(2):196-198.

Castillo, M.S. and A.L. Wright. 2008. Soil phosphorus pools for Histosols under sugarcane and pasture in the Everglades, USA. Geoderma 145:130-135, doi: 10.1016/j.geoderma.2008. 03.006 .

de Resende, G.M., J.E. Yuri, J.H. Mota, J.C. Rodrigues, Junior, R.J. de Souza, and J.G. de Carvalho. 2005. Resposta da alface tipo americana a doses e épocas de aplicação foliar de zinco. Caatinga 18(2):66-72.

de Resende, G.M., J.E. Yuri, and R.J. de Souza. 2008. Épocas de plantio e doses de zinco em alface tipo americana. Hort. Bras. 26(4):510 514, doi: 10.1590/S0102-05362008000400017.

Dittmar, P. and N.S. Boyd. 2020. Weed management in leafy greens (lettuce, endive, escarole, and spinach) (HS203). Univ. of Fla. Inst. of Food \& Agr. Sci., Gainesville. 17 Aug. 2020. $<$ https://edis.ifas.ufl.edu/wg031>

dos Santos, R.F., E. Blume, L.I. Heckler, J. Müller, G.B.P. da Silva, and M.F.B. Muniz. 2014 Solarização do solo associada à aplicação de Trichoderma spp. no controle de Sclerotinia sclerotiorum. Revista de Ciências AgráriasAmazon J. Agr. Environ. Sci. 57(3):322-325, doi: 10.4322/rca.nc1035.

Dufault, R.J., B. Ward, and R.L. Hassell. 2009 Dynamic relationships between field temperatures and romaine lettuce yield and head quality. Scientia Hort. 120(4):452-459, doi: 10.1016/ j.scienta.2009.01.002.
Food and Agriculture Organization of the United Nations. 2020. Crops statistics. 20 June 2020. $<$ http://www.fao.org/faostat/en/\#data/QC $>$.

Freeman, J.H., P.J. Dittmar, and G.E. Vallad. 2019. Commercial vegetable production in Florida. In: P. Dittmar, J. Freeman, M. Paret, and H. Smith (eds.). Vegetable production handbook of Florida, 2019-2020. University of Florida/ IFAS Extension, Gainesville, FL.

Guzman, V.L. 1984. South Bay and Raleigh. Two crisphead lettuce cultivars resistant to corky root rot for organic soils. Food Agr. Sci. Univ. of Florida Agr. Expt. Sta. Circ S-310.

Guzman, V.L. 1986. Short Guzmaine, Tall Guzmaine and Floriglade. Three cos lettuce cultivars resistant to lettuce mosaic virus. Food Agr. Sci. Univ. of Fla. Agr. Expt. Sta. Circ S-326.

Guzman, V.L. and G.L. Raleigh. 1984. Floricrisp 1265 and Floricrisp 1366. Two crisphead lettuces adapted to organic soil production. Food Agr. Sci. Univ. of Fla. Agr. Expt. Sta. Circ S-307.

Guzman, V.L. and T.A. Zitter. 1983. Floricos 83: A cos lettuce cultivar resistant to two viruses, for Florida organics soils. Food Agr. Sci. Univ. of Fla. Agr. Expt. Sta. Circ S-305.

Guzman, V.L. and T.A. Zitter. 1984. Floribibb: A gourmet lettuce resistant to two viruses, for Florida organic soils. Food Agr. Sci. Univ. of Fla. Agr. Expt. Sta. Circ S-313.

Hao, J.H., L.L. Zhang, P.P. Li, Y.C. Sun, J.K. Li, X.X. Qin, L. Wang, Z.Y. Qi, S. Xiao, Y.Y. Han, and C.J. Liu. 2018. Quantitative proteomics analysis of lettuce (Lactuca sativa L.) reveals molecular basis-associated auxin and photosynthesis with bolting induced by high temperature. Intl. J. Mol. Sci. 19(10):2967, doi: 10.3390/ ijms19102967.

Hayes, R.J. 2018. Lettuce production, p. 1-6. In: K.V. Subbarao, R.M. Davis, R.L. Gilbertson, and R.N. Raid (eds.). Compendium of Lettuce Diseases and Pests. 2nd edition. APS Press, St. Paul, MN.

Hochmuth, G.J., D. Maynard, C. Vavrina, E. Hanlon, and E. Simonne. 2018. Plant tissue analysis and interpretation for vegetable crops in Florida (HS964). Univ. of Fla. Inst. of Food \& Agr., Gainesville. Sci. 25 June 2020. $<$ https://edis.ifas.ufl.edu/ep081>.

Holmes, S.C., D.E. Wells, J.M. Pickens, and J.M. Kemble. 2019. Selection of heat tolerant lettuce (Lactuca sativa L.) cultivars grown in deep water culture and their marketability. Horticulturae 5(3):50, doi: 10.3390/horticulturae5030050.

Janardhanan, L. and S.H. Daroub. 2010. Phosphorus sorption in organic soils in south Florida. Soil Sci. Soc. Amer. J. 74(5):1597-1606, doi: 10.2136/sssaj2009.0137.

Jenni, S. and R.J. Hayes. 2010. Genetic variation, genotype $\times$ environment interaction, and selection for tipburn resistance in lettuce in multienvironments. Euphytica 171(3):427-439, doi: 10.1007/s10681-009-0075-5.

Jenni, S., M.J. Truco, and R.W. Michelmore. 2013 Quantitative trait loci associated with tipburn, heat stress-induced physiological disorders, and maturity traits in crisphead lettuce. Theor. Appl. Genet. 126(12):3065-3079, doi: 10.1007/ s00122-013-2193-7.

Jenni, S. and W. Yan. 2009. Genotype by environment interactions of heat stress disorder resistance in crisphead lettuce. Plant Breed. 128(4):374-380, doi: 10.1111/j.1439-0523. 2009.01657.x.

Kanissery, R., R.N. Raid, J. Desaeger, J.W. Noling, J. Beuzelin, and C.F. Miller. 2019. Leafy vegetable production, p. 113-143. In: P. Dittmar, J. Freeman, M. Paret, and H. Smith (eds.). 
Vegetable production handbook of Florida, 2019-2020. University of Florida/IFAS Extension, Gainesville, FL.

Lafta, A. and B. Mou. 2013. Evaluation of lettuce genotypes for seed thermotolerance. HortScience 48(6):708-714, doi: 10.21273/HORTSCI.48. 6.708 .

Lafta, A., T. Turini, G.V. Sandoya, and B. Mou. 2017. Field evaluation of green and red leaf lettuce genotypes in the Imperial, San Joaquin, and Salinas valleys of California for heat tolerance and extension of the growing seasons. HortScience 52(1):40-48, doi: 10.21273/ HORTSCI10835-16.

Mikel, M.A. 2013. Genetic composition of contemporary proprietary U.S. lettuce (Lactuca sativa L.) cultivars. Genet. Resources Crop Evol. 60(1):89-96, doi: 10.1007/s10722-012-9818-6.

Mkhabela, K.T., M.V. Dlamini, and A.M. Manyatsi. 2019. The effect of mulching on soil moisture retention and yield of lettuce (Lactuca sativa L.). Intl. J. Environ. Agr. Res. 5(9):47-50.

Moraes, M.C.H.S., E.V. de Medeiros, D.S. de Andrade, L.D. de Lima, I.C.S. Santos, and A.P. Martins Filho. 2018. Microbial biomass and enzymatic activities in sandy soil cultivated with lettuce inoculated with plant growth promoters. Caatinga 31(4):860-870, doi: 10.1590/1983-21252018v31n408rc.

Mylavarapu, R., W. Harris, and G. Hochmuth. 2019. Agricultural soils of Florida. SL441. Univ. of Fla. Inst. of Food \& Agr. Sci., Gainesville. 7 Sept. 2020. <https://edis.ifas.ufl.edu/ss655>.

Odero, D.C. and A.L. Wright. 2013. Phosphorus application influences the critical period of weed control in lettuce. Weed Sci. 61(3):410 414, doi: 10.1614/WS-D-12-00107.1.

Parkell, N.B., R.C. Hochmuth, and W.L. Laughlin. 2015. An overview of lettuce production systems and cultivars used in hydroponics and protected culture in Florida (HS1258). Univ. of Fla. Inst. of Food \& Agr. Sci., Gainesville. 22 June 2020. <https://edis.ifas.ufl.edu/hs1258>.

Petrazzini, L.L., R.J. de Souza, G.A. Silva, R.G.F. Morales, and D.F. Oliveira. 2010. Crescimento e desenvolvimento da alface americana com deficiência simples e múltipla de nutrientes. Hort. Bras. 29(2):S4003-S4007.

Robles, C.A., D.J. Cantliffe, and G.J. Hochmuth. 1997. Performance of direct seeded and transplanted lettuce grown on the sandy soils of Florida. Proc. Annu. Meet. FL State Hort. Soc. 110:309-314.

Rodriguez, A.F., S. Gerber, and S.H. Daroub. 2020. Modeling soil subsidence in a subtropical drained peatland. The case of the Everglades Agricultural Area. Ecol. Modell. 415:108859, doi: 10.1016/j.ecolmodel.2019.108859.

Roosta, H.R., A. Estaji, and F. Niknam. 2018. Effect of iron, zinc and manganese shortageinduced change on photosynthetic pigments, some osmoregulators and chlorophyll fluorescence parameters in lettuce. Photosynthetica 56(2):606-615, doi: 10.1007/s11099-017-0696-1.

Ryder, E.J. and W. Waycott. 1998. Crisphead lettuce resistant to tipburn: Cultivar Tiber and eight breeding lines. HortScience 33(5):903904, doi: 10.21273/HORTSCI.33.5.903.

Sabat, T., S. Kaniszewski, and J. Dyśko. 2015. Effect of flood fertigation on yield of greenhouse lettuce grown in different substrates. J. Elem. 20(2):407-416, doi: 10.5601/jelem.2014.19.1.626.

Sandoya, G.V. 2019. Advances in lettuce breeding and genetics, p. 459-478. In: G. Hochmuth (ed.). Achieving sustainable cultivation of vegetables. Burleigh Dodds Sci. Pub., London. doi: 10.19103/AS.2019.0045.24.

Sandoya, G.V. and H. Lu. 2020. Evaluation of lettuce cultivars for production on muck soils in southern Florida (HS1225). Univ. of Fla. Inst. of Food \& Agr. Sci. 1-6, Gainesville. 25 June 2020. <https://edis.ifas.ufl.edu/hs1225>.

Santos, B.M., J.A. Dusky, W.M. Stall, D.G. Shilling, and T.A. Bewick. 2003. Influencia de la fertilización fosforada sobre la interferencia de Amaranthus hybridus y Portulaca oleracea en lechuga producida en suelos orgânicos. Manejo Integr. Plagas Agroecol. 67:13-17.

Saxton, A.M. 1998. A macro for converting mean separation output to letter groupings in Proc
Mixed. Proc. Annu. SAS Users Group Int. 23:1243-1246.

Simko, I. 2019. Genetic variation and relationship among content of vitamins, pigments, and sugars in baby leaf lettuce. Food Sci. Nutr. 7(10):3317-3326, doi: 10.1002/fsn3.1196.

Soundy, P., D.J. Cantliffe, G.J. Hochmuth, and P.J. Stoffella. 2005. Management of nitrogen and irrigation in lettuce transplant production affects transplant root and shoot development and subsequent crop yields. HortScience 40(3):607610, doi: 10.21273/HORTSCI.40.3.607.

U.S. Department of Agriculture National Agricultural Statistics Service Information. 2019. Quick Stats. Dept. Agr. Natl. Agr. Stat. Serv. 20 June 2020. <https://quickstats.nass.usda.gov/>.

White, J.M. and V.L. Guzman. 1979. Effect of planting date on the performance of cos lettuce on two central Florida soils. Res. Rpt. CF $80(3): 1-5$.

Wiggins, Z., O. Akaeze, D. Nandwani, and A. Witcher. 2020. Substrate properties and fertilizer rates on yield responses of lettuce in a vertical growth system. Sustainability 12(16):6465, doi: 10.3390/su12166465.

Wright, A.L. and E.A. Hanlon. 2019. Organic matter and soil structure in the Everglades Agricultural Area (SL301).Univ. of Fla. Inst. of Food \& Agr. Sci., Gainesville. 13 Mar. 2020. $<$ https://edis.ifas.ufl.edu/ss514.>.

Yan, W., L.A. Hunt, Q. Sheng, and Z. Szlavnics. 2000. Cultivar evaluation and megaenvironment investigation based on the GGE biplot. Crop Sci. 40(3):597-605, doi: $10.2135 /$ cropsci2000.403597x.

Yan, W. 2001. GGEbiplot - a Windows application for graphical analysis of multienvironment trial data and other types of two-way data. Agron. J. 93(5):1111-1118, doi: 10.2134/ agronj2001.9351111x.

Yuri, J.E., G.M. de Resende, J.H. Mota, R.J. de Souza, and J.G. de Carvalho. 2006. Produção de alface-americana, em função de doses e épocas de aplicação de zinco. Cienc. Agrotec. 30(4):665669, doi: 10.1590/S1413-70542006000400011. 